\title{
Kanttekeningen bij Boskalis/Fugro
}

\author{
Prof. mr. B.F. Assink*
}

Deze kanttekeningen bij Boskalis/Fugro omvatten de reikwijdte van artikel 2:114a BW (art. 2:224a BW), de doorwerking van Europees recht in dat verband, verdeling van bevoegdheden tussen bestuur en algemene vergadering ook aangaande beleid en strategie, en de relevantie van artikel 2:129 BW en artikel 2:107 BW ter zake.

'Het gaat in deze zaak om de vraag of een aandeelhouder/ certificaathouder agendering kan afdwingen van een peiling van standpunten van de ter algemene vergadering aanwezige of vertegenwoordigde aandeelhouders/certificaathouders over een door die aandeelhouder/certificaathouder opgestelde conceptaanbeveling aan het bestuur. In deze zaak ziet het onderwerp van de conceptaanbeveling op een aangelegenheid die tot de bevoegdheid van het bestuur behoort.'

\section{Inleiding}

In HR 20 april 2018, ECLI:NL:HR:2018:652 (Boskalis/ Fugro) $)^{2}$ laat de Hoge Raad zich uit over de uitleg van artikel 2:114a BW, meer in het bijzonder over de vraag of artikel 2:114a BW de daarin bedoelde aandeelhouders en certificaathouders ook het recht geeft de vennootschap te verplichten een onderwerp ter stemming (en dus niet alleen ter bespreking) op de agenda van de algemene vergadering te (doen) plaatsen als de algemene vergadering niet de bevoegdheid toekomt een besluit over dat onderwerp te nemen. De Hoge Raad beantwoordt deze vraag in dit arrest ontkennend. Ik plaats hierna kanttekeningen bij dit arrest.

\section{Casus}

De casus die in cassatie voorligt, is betrekkelijk overzichtelijk en laat zich als volgt samenvatten.

a. Fugro NV ('Fugro') is een beursgenoteerde vennootschap. De aandelen van Fugro zijn genoteerd in de vorm van certificaten van aandelen. Boskalis Holding BV (hierna: Bos-

Prof. mr. B.F. Assink is advocaat bij NautaDutilh, hoogleraar Onderne mingsrecht aan Erasmus School of Law (EUR), en redacteur van WPNR.

Deze bijdrage (afgesloten per 1 juli 2018) is een uitwerking van zijn voordracht op het Van der Heijden Instituut (OO\&R)-symposium 'Bescherming van beursvennootschappen en vitale vennootschappen' gehouden op 29 mei 2018 bij AkzoNobel te Amsterdam.

1. A-G Timmerman in nr. 4.1 voor HR 20 april 2018, ECLI:NL:HR: 2018:652 (Boskalis/Fugro), ook gepubliceerd in RvdW 2018/532.

2. Het hofarrest is gepubliceerd als Hof Den Haag 31 mei 2016, ECLI:NL:GHDHA:2016:1531 (Boskalis/Fugro) (met in JOR 2016/181 een noot van R.G.J. Nowak). De conclusie van A-G Timmerman is apart gepubliceerd als ECLI:NL:PHR:2018:14. Het arrest van de Hoge Raad is ook geannoteerd door A.F.J.A. Leijten in JOR 2018/142. kalis) hield een belang van ruim $28 \%$ in Fugro (welk belang Boskalis ten tijde van het arrest van de Hoge Raad had afgebouwd tot $0 \%$ ).

b. Boskalis heeft bezwaar tegen een door Fugro ingestelde Antilliaanse beschermingsconstructie op het niveau van twee in Curaçao gevestigde dochtervennootschappen van Fugro: deze dochtervennootschappen hebben een calloptie verleend aan de Antilliaanse Stichting Continuïteit Fugro om preferente beschermingsaandelen te verkrijgen (hierna: de Antilliaanse beschermingsconstructie). De moedermaatschappij van Boskalis, Koninklijke Boskalis Westminster NV (hierna: Koninklijke), heeft Fugro verzocht over te gaan tot ontmanteling van de Antilliaanse beschermingsconstructie. Fugro heeft dit geweigerd.

c. Boskalis heeft Fugro vervolgens verzocht om het navolgende agendapunt met toelichting ter stemming op te nemen in de agenda van de algemene vergadering van 30 april 2015:

\section{'Agendapunt}

Aanbeveling aan de Raad van Bestuur en Raad van Commissarissen van Fugro (...) om al hetgeen te doen dat nodig is om te komen tot een onmiddellijke beëindiging van de beschermingsconstructie die is ingesteld op het niveau van twee in Curaçao gevestigde dochtermaatschappijen van Fugro (stempunt).'

Volgens de door Boskalis bij dit agendapunt gegeven toelichting wordt van Fugro de volgende actie verlangd:

'Voor ontmanteling van de constructie is vereist dat de Raad van Bestuur en Raad van Commissarissen van Fugro de daartoe strekkende besluiten nemen en deze vervolgens ten uitvoer leggen. Indien daarvoor de medewerking nodig is van de Antilliaanse Stichting Continuiteit Fugro, dienen de Raad van Bestuur en de Raad van Commissarissen van Fugro al hetgeen te doen dat nodig is om deze medewerking te verkrijgen, dan wel af te dwingen.'

Fugro heeft Boskalis meegedeeld dat zij (1) niet bereid is het door Boskalis voorgedragen agendapunt ter stemming op te nemen in de agenda van de algemene vergadering en (2) wel bereid is het onderwerp ter bespreking te agenderen en de door Boskalis geformuleerde toelichting in de agenda op te nemen.

d. Boskalis vordert daarop in kort geding Fugro te bevelen het in sub c hiervoor genoemde agendapunt ter stemming op te nemen in de agenda van de eerstvolgende algemene 


\section{Maandblad}

Ondernemingsrecht

vergadering van Fugro. De voorzieningenrechter heeft de vordering afgewezen. Het hof heeft het vonnis van de voorzieningenrechter bekrachtigd.

e. Daartoe heeft het hof - kort gezegd - overwogen dat de voorzieningenrechter met juistheid heeft geoordeeld dat de door Boskalis geformuleerde aanbeveling geen onderwerp betreft ten aanzien waarvan de algemene vergadering de bevoegdheid toekomt een besluit te nemen, dat dit betekent dat Fugro niet verplicht is de aanbeveling van Boskalis ter (informele) stemming op de agenda van de algemene vergadering te plaatsen, en dat de Richtlijn 2007/36/EG betreffende de uitoefening van bepaalde rechten van aandeelhouders in beursgenoteerde vennootschappen (hierna: Aandeelhoudersrichtlijn) ${ }^{3}$ hieraan niet in de weg staat.

f. Het cassatieberoep van Boskalis richt zich tegen dit oordeel van het hof in sub e hiervoor. ${ }^{4}$

\section{Middel}

In cassatie voert Boskalis in de kern twee rechtsklachten aan tegen het oordeel van het hof.

a. Onderdelen 1-2. Het hof heeft miskend dat op grond van artikel 2:114a BW de daar genoemde aandeelhouder of certificaathouder ook het recht heeft om de vennootschap te verzoeken een onderwerp ter stemming (en dus niet alleen ter bespreking) op de agenda van de algemene vergadering te plaatsen als de algemene vergadering niet de bevoegdheid toekomt een besluit over dat onderwerp te nemen, maar wel de bevoegdheid toekomt hierover een standpunt in te nemen (bijvoorbeeld door een motie, een informele stemming, een beslissing zonder rechtsgevolg, een aanbeveling of een peiling). In ieder geval heeft het hof het voorgaande miskend als dat standpunt van de algemene vergadering de structuur van de vennootschap betreft en niet de strategie.

b. Onderdeel 3. Het hof heeft miskend dat de Aandeelhoudersrichtlijn meebrengt dat als uitgangspunt geldt dat een aandeelhouder een ongeclausuleerd agenderingsrecht toekomt in die zin dat het recht om punten op de agenda van de algemene vergadering te (doen) plaatsen niet afhankelijk is van, en niet mag worden beperkt door, een voorafgaande toetsing door (het bestuur van) de vennootschap

3. De Aandeelhoudersrichtlijn is nadien gewijzigd in Richtlijn 2017/828/ EU betreffende het bevorderen van de langetermijnbetrokkenheid van aandeelhouders, maar niet wat betreft de hier relevante onderdelen, in het bijzonder art. 6 .

4. In deze procedure heeft Fugro zich nog beroepen op niet-ontvankelijkheid van Boskalis in haar cassatieberoep wegens berusting in de zin van art. $400 \mathrm{Rv}$, dit laatste naar aanleiding van uitlatingen van een functionaris van Koninklijke (de 'Director of Investor Relations \& Corporate Communications') op 31 mei 2016 (de dag waarop het hof het in cassatie bestreden arrest heeft gewezen) tegenover het persbureau ABM Financial News, waarna laatstgenoemde op diezelfde dag het volgende bericht op zijn website (www.deaandeelhouder.nl) heeft geplaatst: 'Baggerconcern legt zich neer bij uitspraak en gaat niet in cassatie.' Daarover besliste de Hoge Raad in HR 10 maart 2017, ECLI:NL:HR:2017:412 (Boskalis/Fugro), r.o. 3.3.2-3.3.6 (ook gepubliceerd in NJ 2017/135) dat daarmee niet was voldaan aan de voorwaarden voor berusting. Ik laat dat rusten. of, en in welke vorm, het voorgestelde punt zich al dan niet leent voor een dialoog met de vennootschap, hetgeen meebrengt dat een aandeelhouder het recht heeft een aanbeveling als punt op de agenda te (doen) plaatsen en dat agendapunt in stemming te brengen (in de vorm van een peiling of motie).

\section{Arrest}

Deze rechtsklachten lenen zich voor gezamenlijke behandeling, aldus de Hoge Raad in r.o. 3.3.1, die deze vervolgens in r.o. 3.3.2-3.3.9 als volgt behandelt: ${ }^{5}$

\section{3 .2}

Art. 2:109 BW bepaalt dat het bestuur en de raad van commissarissen bevoegd zijn tot het bijeenroepen van een algemene vergadering. Art. 2:114 lid 1, aanhef en onder a, BW bepaalt dat bij de oproeping de te behandelen onderwerpen worden vermeld. Uit de bevoegdheid van het bestuur en de raad van commissarissen tot bijeenroeping volgt de bevoegdheid van deze organen tot vaststelling van de agenda en dus tot vaststelling van de te behandelen onderwerpen.

\subsection{3}

Art. 2:114a BW makt op het hiervoor overwogene in zoverre een uitzondering dat een onderwerp waarvan de behandeling tijdig schriftelijk is verzocht door een of meer aandeelhouders die alleen of gezamenlijk ten minste drie procent van het geplaatste kapitaal vertegenwoordigen, wordt opgenomen in de oproeping. Deze bepaling geldt ook voor houders van certificaten van aandelen die met medewerking van de vennootschap zijn uitgegeven.

\subsection{4}

Uit de parlementaire geschiedenis van art. 2:114a BW (zie de citaten daaruit in de conclusie van de Advocaat-Generaal onder 4.17 en 4.24-4.26) volgt dat de in deze bepaling geregelde bevoegdheid beoogt bij te dragen aan de uitoefening van de eigen wettelijke bevoegdheden van de algemene vergadering en aan verbetering van het functioneren van de algemene vergadering als orgaan waaraan het bestuur en de raad van commissarissen verantwoording afleggen over het gevoerde beleid. Tevens volgt daaruit dat een onderwerp waarvan de behandeling is verzocht, een onderwerp kan zijn waarvoor aan de algemene vergadering geen wettelijke of statutaire bevoegdheid tot besluitvorming toekomt. Een verzoek op grond van art. 2:114a BW kan slechts in uitzonderlijke gevallen worden geweigerd. Een grondslag voor zo'n weigering kan gelegen zijn in art. 2:8 lid $2 \mathrm{BW}$ of art. 3:13 lid $1 \mathrm{BW}$.

5. Ook de overige klachten van het middel kunnen niet tot cassatie leiden, zo leert de Hoge Raad in r.o. 3.4, waarin deze klachten op basis van art. $81 \mathrm{RO}$ worden afgedaan. 


\section{Maandblad}

Ondernemingsrecht

\subsection{5}

Het middel stelt de vraag aan de orde of art. 2:114a BW de daarin bedoelde aandeelhouders en certificaathouders ook het recht geeft de vennootschap te verplichten een onderwerp ter stemming (en dus niet alleen ter bespreking) op de agenda van de algemene vergadering te (doen) plaatsen als de algemene vergadering niet de bevoegdheid toekomt een besluit over dat onderwerp te nemen.

\subsection{6}

Voor het antwoord op die vraag is het volgende van belang.

Het bepalen van het beleid en de strategie van een vennootschap en de met haar verbonden onderneming is in beginsel een aangelegenheid van het bestuur van de vennootschap. De raad van commissarissen houdt daarop toezicht. De algemene vergadering kan haar opvattingen terzake tot uitdrukking brengen door uitoefening van de haar in de wet en de statuten toegekende rechten. Dit laatste betekent in het algemeen dat het bestuur van een vennootschap aan de algemene vergadering verantwoording heeft af te leggen van zijn beleid, maar dat het, behoudens afwijkende wettelijke of statutaire regelingen, niet verplicht is de algemene vergadering vooraf in zijn besluitvorming te betrekken als het gaat om handelingen waartoe het bestuur bevoegd is. Ook is het bestuur niet verplicht de algemene vergadering in zo'n geval te consulteren. (Vgl. HR 13 juli 2007, ECLI:NL:HR:2007:BA7972, NJ 2007/434 (ABN Amro), rov. 4.3-4.4 en HR 9 juli 2010, ECLI:NL:HR: 2010:BM0976, NJ 2010/544(ASMI), rov. 4.4.1)

Het bestuur heeft een eigen verantwoordelijkheid om zich te richten naar het belang van de vennootschap en de met haar verbonden onderneming (vgl. HR 4 april 2014, ECLI:NL:HR:2014:797, NJ 2014/286 (Cancun), rov. 4.3). Dat belang kan de invoering, handhaving of beëindiging meebrengen van een bepaalde inrichting van de (vennootschappelijke) organisatie. Daarbij geldt dat iedere vennootschap binnen de grenzen van de wet vrij is haar (vennootschappelijke) organisatie naar eigen inzicht in te richten (vgl. de hiervoor vermelde beschikking van 9 juli 2010, rov. 4.4 .2 onder (iv)). Voor zover bevoegdheden omtrent de inrichting van de (vennootschappelijke) organisatie toekomen aan het bestuur, valt de uitoefening daarvan samen met het bepalen van het beleid en de strategie van de vennootschap.

\subsection{7}

Het hiervoor in 3.3.6 overwogene stelt grenzen aan de in art. 2:114a BW geregelde bevoegdheid van de daarin bedoelde aandeelhouders en certificaathouders. $\mathrm{Nu}$ het bepalen van het beleid en de strategie van een vennootschap en de met haar verbonden onderneming in beginsel een aangelegenheid is van het bestuur van de vennootschap en het bestuur niet verplicht is de algemene vergadering daaromtrent te consulteren, kunnen de in art. 2:114a BW bedoelde aandeelhouders en certificaathouders de vennootschap niet ertoe verplichten een onderwerp dat een aangelegenheid is van het bestuur ter stemming op te nemen in de agenda van de algemene vergadering. Daarbij doet niet ter zake dat die stemming geen rechtsgevolg heeft en wordt betiteld als een informele stemming, een aanbeveling, een motie of een peiling.

\subsection{8}

Naar buiten redelijke twijfel staat, dwingt het in de Aandeelhoudersrichtlijn bepaalde niet tot een andere conclusie. Belangrijke doelstellingen van deze richtlijn zijn het opheffen van belemmeringen die aandeelhouders ontmoedigen van hun stemrechten gebruik te maken, en aandeelhouders de mogelijkheid te bieden hun rechten overal in de Unie effectief uit te oefenen (punten 3, 4 en 14 van de considerans van de Aandeelhoudersrichtlijn). Art. 6 Aandeelhoudersrichtlijn bepaalt onder meer dat de lidstaten ervoor zorgen dat aandeelhouders, hetzij individueel, hetzij collectief optredend, a) het recht hebben punten op de agenda van de algemene vergadering te plaatsen, mits elk van die punten wordt gemotiveerd of vergezeld gaat van een ontwerpresolutie ter goedkeuring op de algemene vergadering; en b) het recht hebben met betrekking tot op de agenda voor een algemene vergadering opgenomen of daarin op te nemen punten ontwerpresoluties in te dienen. Uit de hiervoor genoemde doelstellingen van de Aandeelhoudersrichtlijn en de bewoordingen van art. 6 Aandeelhoudersrichtlijn kan worden afgeleid dat is beoogd rechten voor aandeelhouders te versterken die bijdragen aan het effectief kunnen uitoefenen van stemrechten door aandeelhouders. Niet blijkt dat is beoogd aandeelhouders stemrechten toe te kennen die zij voordien niet hadden. Ook blijkt niet dat is beoogd de bevoegdheidsverdeling tussen de verschillende organen van de vennootschap nader te regelen.

Uit het voorgaande volgt dat art. 6 Aandeelhoudersrichtlijn niet dwingt tot een andere uitleg van art. 2:114a BW dan hiervoor in 3.3.6-3.3.7 is gegeven. Dit strookt met de wijze waarop art. 6 Aandeelhoudersrichtlijn is geïmplementeerd in het recht van België, Duitsland en Frankrijk (zie hierover de beschouwingen in de conclusie van de Advocaat-Generaal onder 4.106-4.112, 4.117-4.121 en 4.125-4.127). In geen van die landen heeft de Aandeelhoudersrichtlijn ertoe geleid dat aandeelhouders een stemming van de algemene vergadering kunnen afdwingen over onderwerpen die niet tot de bevoegdheid van de algemene vergadering behoren.

\subsection{9}

Uit het voorgaande volgt dat alle rechtsklachten van het middel falen.' 


\section{Maandblad}

Ondernemingsrecht

\section{Kanttekeningen}

\subsection{Voorliggende vraag}

Het arrest gaat niet specifiek over 'bescherming' van een vennootschap zoals dat doorgaans wordt geduid, in het bijzonder in de zin van bescherming tegen een vijandige bieder zoals bijvoorbeeld wel speelde in de RNA-beschikking van de Hoge Raad. ${ }^{6}$ Het arrest is toegespitst op de bredere en meer algemene vraag die de Hoge Raad centraal stelt in r.o. 3.3.5 ten aanzien van de uitleg van artikel 2:114a BW, zoals logisch ingekaderd in r.o. 3.3.2-3.3.3: ${ }^{7}$

'Geeft art. 2:114a BW de daarin bedoelde aandeelhouders of certificaathouders het recht de vennootschap te verplichten een onderwerp ter stemming (en dus niet alleen ter bespreking) op de agenda van de algemene vergadering te (doen) plaatsen, dus als bijeenkomst van aandeelhouders, als de algemene vergadering, dus als orgaan, niet de bevoegdheid toekomt een besluit over dat onderwerp te nemen?'

Hierna ga ik kortweg uit van een ex artikel 2:114a BW verzoekende aandeelhouder, maar dat kan dus ook een certificaathouder zijn.

\subsection{Relativering}

Bij de voorgaande opmerking over 'bescherming' van een vennootschap past een relativering op enkele niveaus.

Ten eerste dat het beschermingsaspect in dit geval natuurlijk wel op de achtergrond speelde, waarvan de Hoge Raad deels ook blijkt geeft in zijn weergave van de feiten in r.o. 3.1. Niet alleen door het onderwerp van het agenderingsverzoek van Boskalis, dat betrekking had op ontmanteling van de Antilliaanse beschermingsconstructie, maar ook, en in verband daarmee, door de kennelijke wens van Boskalis tot een overname van Fugro te komen. ${ }^{8}$ De Hoge Raad verwijst daar verder niet naar in zijn dragende overwegingen.

6. HR 18 april 2003, NJ 2003/286 (RNA).

7. Logisch, nu art. 2:114a BW moet worden beschouwd als een bepaling (waarvan de kern wordt beschreven in r.o. 3.3.3) met een uitzonderingskarakter, aldus dat deze bepaling een uitzondering maakt op het uitgangspunt (waarvan de kern wordt beschreven in r.o. 3.3.2) dat de bevoegdheid tot vaststelling van de agenda voor de algemene vergadering, en dus tot vaststelling van de daarin te behandelen onderwerpen, toekomt aan het bestuur en de raad van commissarissen (zo dat orgaan is ingesteld), welke bevoegdheid weer volgt uit de bevoegdheid van het bestuur en de raad van commissarissen ex art. 2:109 BW een algemene vergadering bijeen te roepen (waarbij art. 2:114 lid 1, aanhef en sub a BW dan weer bepaalt dat bij de oproeping de te behandelen onderwerpen worden vermeld). Ik wijs nog op best practice 4.1.3 van de Nederlandse Corporate Governance Code, waaruit mede volgt dat op die agenda wordt vermeld welke punten ter bespreking en welke punten ter stemming zijn.

8. Hierover is het nodige gepubliceerd, zoals: 'Boskalis koopt alternatief voor misgelopen prooi Fugro', FD 16 augustus 2017, p. 13. Terzijde: Fugro had naast de Antilliaanse beschermingsconstructie nog twee beschermingsconstructies. Dit laatste verklaart denkelijk waarom Boskalis handelde zoals het deed en niet 'gewoon' een voorgenomen openbaar bod aankondigde.
Ten tweede, en in het verlengde van het voorgaande, dat wat de Hoge Raad overweegt met betrekking tot artikel 2:114a BW kan opspelen in een volgend geval waarin een vennootschap zich geconfronteerd ziet met een vijandige bieder. Met het arrest in de hand kan zij, specifiek het bestuur, in beginsel met kracht weigeren een agendapunt ter stemming op te nemen als dat punt niet valt onder de bevoegdheid van de algemene vergadering, zoals het ontmantelen van een bepaalde beschermingsconstructie waarover in beginsel het bestuur - en niet de algemene vergadering - gaat.

Ten derde dat, als 'bescherming van een vennootschap' breder wordt getrokken, daaronder ook kan worden verstaan de bescherming van het gevoerde beleid en de gevolgde strategie tegen, wat ik maar even noem, 'activistische aandeelhouders' (die niet uit zijn op overname van de vennootschap, maar wel op een beleidsmatige/strategische koerswijziging op de kortere termijn, omdat daarmee voordeel te behalen valt voor die aandeelhouder), ${ }^{9}$ dan biedt dit arrest het bestuur in beginsel ook de mogelijkheid met kracht tot zo'n weigering ex artikel 2:114a BW over te gaan.

Ten vierde dat, door die bescherming nog weer breder te trekken, dit arrest het bestuur van een vennootschap juridisch ruimte biedt via zo'n weigering ex artikel 2:114a BW regie te houden over het al dan niet voeren van tussentijdse discussies over het gevoerde beleid en de gevolgde strategie (los van de tweede en derde situaties hiervoor) ${ }^{10}$ uitmondend in besluitvorming door de algemene vergadering, vóórdat daarover door het bestuur jegens de algemene vergadering verantwoording wordt afgelegd (wat doorgaans periodiek achteraf gebeurt in de jaarlijkse algemene vergadering als bedoeld in art. 2:108 lid $1 \mathrm{BW}) .{ }^{11}$

Voor de goede orde: zo'n weigering in de tweede, derde en vierde situaties hiervoor moet worden onderscheiden van de overwegingen van de Hoge Raad in r.o. 3.3.4 (1) dat een verzoek op grond van artikel 2:114a BW' slechts in uitzonderlijke gevallen' kan worden geweigerd en (2) dat een grondslag voor zo'n weigering gelegen kan zijn in artikel 2:8 lid $2 \mathrm{BW}$ of artikel 3:13 lid $1 \mathrm{BW}$. Bij de dáár door de Hoge Raad bedoelde weigering gaat het om een verzoek ex artikel 2:114a BW (1) een onderwerp ter bespreking op de agenda van de algeme-

9. Illustratief zijn HR 18 juli 2007, NJ 2007/434 (ABN Amro), r.o. 3.1.xxv en HR 9 juli 2010, NJ 2010/544 (ASMI), r.o. 3.1.vi-vii.

10. Wat zou passen bij HR 9 juli 2010, NJ 2010/544 (ASMI), r.o. 4.4.4.i, waarin de Hoge Raad overweegt dat 'uit het feit dat externe aandeelhouders het oneens zijn met het beleid van het bestuur en de $\mathrm{RvC}$, niet zonder meer kan volgen dat het bestuur gehouden is op de visie van die externe aandeelhouders in te gaan en door dat niet te doen blijk geeft van een defensieve en gesloten opstelling'.

11. Zie in dit verband ook de verwijzing in r.o. 3.3.6 naar de plicht van het bestuur van een vennootschap aan de algemene vergadering achteraf verantwoording af te leggen verantwoording van zijn beleid, te onderscheiden van de - in beginsel niet bestaande - plicht van het bestuur 'de algemene vergadering vooraf in zijn besluitvorming te betrekken als het gaat om handelingen waartoe het bestuur bevoegd is', e.e.a. onder verwijzing naar HR 18 juli 2007, NJ 2007/434 (ABN Amro), r.o. 4.3-4.4 en HR 9 juli 2010, NJ 2010/544 (ASMI), r.o. 4.4.1. 


\section{Maandblad}

Ondernemingsrecht

ne vergadering te (doen) plaatsen of (2) een onderwerp óók ter stemming op de agenda van de algemene vergadering te (doen) plaatsen als de algemene vergadering de bevoegdheid toekomt een besluit over dat onderwerp te nemen, waarbij telkens is voldaan aan de specifieke eisen die artikel 2:114a lid 1 BW stelt.

\subsection{Bespreekpunt}

De Hoge Raad bevestigt dat artikel 2:114a BW de daarin bedoelde aandeelhouders (of certificaathouders) wél het recht geeft de vennootschap te verplichten een onderwerp ter bespreking op de agenda van de algemene vergadering te (doen) plaatsen, ook als de algemene vergadering niet de bevoegdheid toekomt een besluit over dat onderwerp te nemen.

Die bevestiging volgt m.i. uit r.o. 3.3.4, waarin hij memoreert dat uit de wetsgeschiedenis van artikel 2:114a BW volgt dat 'dat een onderwerp waarvan de behandeling is verzocht, een onderwerp kan zijn waarvoor aan de algemene vergadering geen wettelijke of statutaire bevoegdheid tot besluitvorming toekomt', bezien in combinatie met r.o. 3.3.5-3.3.8 waarin besloten ligt dat agendering van zo'n onderwerp ook als stempunt dan niet op grond van artikel 2:114a BW afgedwongen kan worden door de daarin bedoelde aandeelhouder (of certificaathouder), ${ }^{12}$ maar als bespreekpunt in beginsel ${ }^{13}$ wel.

De vennootschap mág dan via het bestuur (of de raad van commissarissen) wel tot agendering van zo'n onderwerp ook als stempunt (dus niet alleen als bespreekpunt) overgaan, maar hoeft dat dan niet te doen, althans niet op basis van artikel 2:114a BW. ${ }^{14}$ Daarbij geldt mede de eigen verantwoordelijkheid van het bestuur zich te richten naar het belang van de vennootschap en de met haar verbonden onderneming, die de Hoge Raad memoreert in r.o. 3.3.6 onder verwijzing naar een van zijn Cancun-beschikkingen, ${ }^{15}$ en waarover advocaat-generaal Timmerman ook behartigenswaardige opmerkingen maakt in zijn conclusie. ${ }^{16}$

Hier laat zich een parallel trekken met de overweging van de Hoge Raad in de ASMI-beschikking ${ }^{17}$ dat de raad van commissarissen geen verplichting heeft een bemiddelende rol te vervullen bij conflicten tussen het bestuur en één of meer aandeelhouders, en dienaangaande aan de aandeelhouders ook

12. De Hoge Raad rept in r.o. 3.3.7 van 'niet ertoe verplichten'.

13. Zie de laatste twee zinnen van r.o. 3.3.4.

14. Zijn ter zake jegens de algemene vergadering gerechtvaardigde verwachtingen gewekt door - het bestuur (en/of de raad van commissarissen) van - de vennootschap, dan kan art. 2:8 lid $1 \mathrm{BW}$ m.i. meebrengen dat een dergelijke gehoudenheid wel bestaat. Maar dit hangt af van de omstandigheden van het geval en is dan in ieder geval niet louter gebaseerd op art. 2:114a BW.

15. HR 4 april 2014, NJ 2014/286 (Cancun), r.o. 4.3. Die gehoudenheid bestaat ook voor de - leden van de - raad van commissarissen, mede gelet op art. 2:140 lid $2 \mathrm{BW}$.

16. A-G Timmerman in nrs. 4.82-4.83 van zijn conclusie, ook over de voorzitter van de algemene vergadering.

17. HR 9 juli 2010, NJ 2010/544 (ASMI), r.o. 4.5.1-4.5.2. geen verantwoording verschuldigd is, maar door één of meer aandeelhouders wel kan worden benaderd met verzoeken om bemiddeling of anderszins en dan vanuit zijn eigen takopdracht adequaat zal moeten handelen, met inachtneming van zijn beoordelings- en beleidsvrijheid bij de vervulling van zijn taak en het vennootschappelijk belang als normatief richtsnoer.

\subsection{Stempunt}

De Hoge Raad beantwoordt de centrale vraag van r.o. 3.3.5 uiteindelijk ontkennend in r.o. 3.3.6-3.3.9, zoveel is duidelijk. In mijn woorden:

'Artikel 2:114a BW geeft de daarin bedoelde aandeelhouders (of certificaathouders) níet het recht de vennootschap te verplichten een onderwerp óók ter stemming op de agenda van de algemene vergadering te (doen) plaatsen, als de algemene vergadering niet de bevoegdheid toekomt een besluit over dat onderwerp te nemen. Dit geldt ook als die stemming geen rechtsgevolg heeft en wordt betiteld als een informele stemming, een aanbeveling, een motie of een peiling. ${ }^{\prime 18}$

Wat mij daaraan opvalt, is niet zozeer dat de Hoge Raad tot dit antwoord komt, als wel de weg die hij kiest om daar te komen.

Ik had verwacht dat, nu het hier in wezen gaat over 'uitleg van art. 2:114a BW', ${ }^{19}$ bij die beantwoording ten minste ook nadrukkelijk, en in de eerste plaats, zou worden aangeknoopt bij de wetgeschiedenis van artikel 2:114a BW, in het bijzonder ook ten tijde van de implementatie van de Aandeelhoudersrichtlijn. Daaruit blijkt immers al (1) dat met de wijziging van artikel 2:114a BW (oud) vanwege de Aandeelhoudersrichtlijn geen verandering is gekomen in de regel van artikel 2:107 lid 1 BW en (2) dat als een aandeelhouder (of certificaathouder) ex artikel 2:114a BW een onderwerp wil laten agenderen en het punt op de agenda wordt geplaatst, hierover 'een beraadslaging' kan plaatsvinden (dus wel bespreking), maar dat wanneer de algemene vergadering geen bevoegdheid bezit om over het onderwerp te besluiten, de voorzitter het onderwerp 'niet in stemming [zal] brengen' (dus geen besluitvorming). ${ }^{20}$ Uit de tekst van artikel 2:114a BW blijkt niets anders, evenmin uit de ratio ervan die ook volgt uit de wetsgeschiedenis en in r.o. 3.3.4 wordt herhaald ('beoogt'). ${ }^{21}$

18. In het arrest ging het om de bevoegdheden van het bestuur en van de algemene vergadering. Het antwoord dat de Hoge Raad op de in r.o. 3.3.5 gestelde centrale vraag geeft, is m.i. ook toepasbaar op bevoegdheden van de raad van commissarissen i.p.v. die van het bestuur.

19. Aldus de Hoge Raad zelf in r.o. 3.3.8.

20. Kamerstukken II 2008/09, 31746, 7, p. 12. In gelijke zin Kamerstukken I 2009/10, 71746, C, p. 6.

21. Let wel, wat A-G Timmerman opmerkt in nr. 4.19 van zijn conclusie ziet alleen op de wetsgeschiedenis van art. 2:114a BW ten tijde van de invoering ervan in 2004, niet op die latere wetsgeschiedenis van art. 2:114a BW als hiervoor genoemd en bedoeld. 


\section{Maandblad \\ Ondernemingsrecht}

Kortom: dit alles wijst er toch wel sterk op dat artikel 2:114a $\mathrm{BW}$, indien toegepast, geen bevoegdheid schept van de algemene vergadering met betrekking tot het voorliggende agendapunt als zij die niet al had en dan evenmin aanspraak geeft op het (doen) plaatsen van dat onderwerp op de agenda óók ter stemming. Advocaat-generaal Timmerman verwees in zijn conclusie nadrukkelijk en bij herhaling naar die wetsgeschiedenis (daarbij langs vergelijkbare lijn redenerend), ${ }^{22}$ en ook het hof zat op die lijn als onderbouwing van zijn oordeel. ${ }^{23}$ In het arrest kan ik niet lezen dat de Hoge Raad deze lijn doortrekt.

\subsection{Rechtspraak}

De Hoge Raad noemt die wetsgeschiedenis wel deels in r.o. 3.3.4, maar benoemt het in paragraaf 5.4 hiervoor genoemde wezenlijke punt daarin niet (het staat er niet en de verwijzingen naar de conclusie zijn ter zake incompleet) en betrekt die wetsgeschiedenis in r.o. 3.3.5-3.3.9 zelfs helemaal niet meer, althans niet kenbaar. Kennelijk is hij van oordeel dat de wetsgeschiedenis ter zake onvoldoende houvast biedt voor het al dan niet mede op basis daarvan beantwoorden van de in r.o. 3.3.5 geformuleerde vraag. Zijn antwoord in r.o. 3.3.7 op die vraag hangt geheel op r.o. $3.3 .6,{ }^{24}$ en die passage in het arrest gaat welbeschouwd over iets anders, namelijk: de vraag wie 'in beginsel' het beleid en de strategie van de vennootschap bepaalt en de betrokkenheid van de algemene vergadering daarbij (in vorm en tijd), ${ }^{25}$ waarover de Hoge Raad zich eerder uitliet in zijn beschikkingen inzake $\mathrm{HBG},{ }^{26} \mathrm{ABN} \mathrm{Amro}^{27}$ en ASMI. ${ }^{28}$

Nou strookt deze rechtspraak in die zin wel met het antwoord dat wordt gegeven in r.o. 3.3.7 over de uitleg van artikel 2:114a BW, dat bij een andere uitleg van artikel 2:114a BW in een geval als het onderhavige zou worden opgeschoven richting een verkapte consultatieplicht van het bestuur (met

22. A-G Timmerman in nrs. 4.24, 4.41, 4.47-4.80, 4.88 van zijn conclusie. De Hoge Raad verwijst in r.o. 4.3.4 wel naar nr. 4.24, maar niet naar de andere nummers.

23. Het hof in r.o. 22-23.

24. De Hoge Raad opent (1) in r.o. 3.3.6 met de zin dat voor het antwoord op de in r.o. 3.3.5 gestelde vraag 'het volgende van belang [is]' (dus de rest van r.o. 3.3.6) en (2) in r.o. 3.7 met: 'Het hiervoor in 3.3.6 overwogene stelt grenzen aan de in art. 2:114a BW geregelde bevoegdheid van de daarin bedoelde aandeelhouders en certificaathouders'.

25. De 'in beginsel'-clausulering is niet terug te vinden in principe 1.1 van (en de toelichting daarop in) de Nederlandse Corporate Governance Code.

26. HR 21 februari 2003, NJ 2003/182 (HBG), r.o. 6.1-6.8.3.

27. HR 18 juli 2007, NJ 2007/434 (ABN Amro), r.o. 4.1-4.10.

28. HR 9 juli 2010, NJ 2010/544 (ASMI), r.o. 4.4.1-4.4.2. A.F.J.A. Leijten merkt in nr. 5 bij JOR 2018/142 op: 'Het valt op dat de Hoge Raad in r.o. 3.3.6-3.3.7 tot drie keer toe het bepalen van "het beleid en de strategie" noemt en dat is voor het eerst. In de ABN Amro- en ASMI-beschikkingen valt alleen het woord "strategie"'. Het is waar dat de Hoge Raad in r.o. 3.3.6-3.3.7 voor het eerst meer precies verwijst naar 'beleid en strategie', maar deze begrippen kwamen beide ook al voor in HR 9 juli 2010 , NJ 2010/544 (ASMI), r.o. 4.4.1, 4.4.2.i-ii, 4.5.1, 4.5.3, zowel individueel ('beleid', 'strategie') als in combinatie ('gevoerde beleid en gevolgde strategie'). Zó nieuw is deze samenstelling dus ook weer niet, al lijkt de hantering ervan in r.o. 3.3.6 wel een functie te hebben; zie noot 78 hierna. besluitvorming door de algemene vergadering) zonder dat de wet en de statuten daarin specifiek voorzien, wat niet goed te rijmen zou zijn met die rechtspraak nu daarin bij herhaling is geoordeeld dat zonder wettelijke of statutaire grondslag geen consultatieplicht bestaat. ${ }^{29}$ Maar uit deze rechtspraak, die niet gaat over artikel 2:114a BW, blijkt niet zonder meer hoe artikel 2:114a BW uitgelegd moet worden, terwijl daarin wel wordt benadrukt, wat de Hoge Raad herhaalt in r.o. 3.3.6, dat de algemene vergadering haar opvattingen ter zake 'tot uitdrukking [kan] brengen door uitoefening van haar in de wet en de statuten toegekende rechten', wat ook raakt aan artikel 2:114a BW en de uitleg daarvan.

Zijn verwijzingen in r.o. 3.3.6 naar die Cancun-beschikking ${ }^{30}$ (de eigen verantwoordelijkheid van het bestuur zich te richten naar het belang van de vennootschap en de met haar verbonden onderneming) en naar die ASMI-beschikking ${ }^{31}$ (de vrijheid van iedere vennootschap binnen de grenzen van de wet haar (vennootschappelijke) organisatie naar eigen inzicht in te richten) maken dit niet anders, want gaan eveneens over iets anders dan artikel 2:114a BW. De eerstgenoemde verwijzing laat overigens wel weer zien dat de Hoge Raad ook hier in r.o. 3.3.6 algemeen over 'vennootschap' schrijft en dit niet heel scherp toesnijdt op bijvoorbeeld besloten of open verhoudingen, iets waarvan die Cancun-beschikking zelf trouwens ook al blijk gaf getuige de verwijzing daarin naar rechtspraak in gevallen met beursvennootschappen (nv's), terwijl het in die beschikking ging om een joint venture-vennootschap (een bv). ${ }^{32}$

\subsection{Varianten}

Misschien loopt door die fixatie van de Hoge Raad op r.o. 3.3.6 de redenering in r.o. 3.3.7 op het oog ook niet helemaal rond, want daarin wordt het algemene bereik van artikel 2:114a BW, ${ }^{33}$ conform de in algemene bewoordingen gestelde centrale vraag van r.o. 3.3.5, helemaal opgehangen aan wat in casu voorlag met betrekking tot beleid- en strategiebepaling en betrokkenheid van de algemene vergadering daarbij, onder verwijzing naar r.o. 3.3.6.

De vraag rijst dan waarom hetzelfde zou moeten gelden als het onderwerp van het agenderingsverzoek ex artikel 2:114a BW

29. Voor het eerst in HR 21 februari 2003, NJ 2003/182 (HBG), r.o. 6.4.2, specifiek herhaald in HR 18 juli 2007, NJ 2007/434 (ABN Amro), r.o. 4.4, en minder specifiek herhaald in HR 9 juli 2010, NJ 2010/544 (ASMI), r.o. 4.4.1.

30. HR 4 april 2014, NJ 2014/286 (Cancun), r.o. 4.3, waarin de Hoge Raad dit afleidt uit r.o. 4.2.1-4.2.3 ('Uit hetgeen hiervoor in 4.2.1-4.2.3 is overwogen, volgt immers (...)')

31. HR 9 juli 2010, NJ 2010/544 (ASMI), r.o. 4.4.2.iv.

32. Zie nader o.a. B.F. Assink, Familievennootschap en vennootschappelijk belang, in: A.J.S.M. Tervoort et al., Familievennootschappen, Deventer: Wolters Kluwer 2017, p. 46.

33. Zie r.o. 3.3.7 slot: '(...) kunnen de in art. 2:114a BW bedoelde aandeelhouders en certificaathouders de vennootschap niet ertoe verplichten een onderwerp dat een aangelegenheid is van het bestuur ter stemming op te nemen in de agenda van de algemene vergadering. Daarbij doet niet ter zake dat die stemming geen rechtsgevolg heeft en wordt betiteld als een informele stemming, een aanbeveling, een motie of een peiling'. 


\section{Maandblad}

Ondernemingsrecht

níet ziet op bepaling van het beleid en de strategie van de vennootschap (meer macro), maar wel onder de bevoegdheid van het bestuur valt, zoals een specifieke beslissing/handeling vallend binnen de bestuurlijke taakvervulling met betrekking tot de dagelijkse aansturing van de onderneming (meer micro). ${ }^{34}$ Dat het antwoord dan logischerwijs hetzelfde zou moeten zijn, gelet ook op de wetsgeschiedenis van artikel 2:114a BW, laat onverlet dat dit antwoord dan niet per se volgt uit de overweging in r.o. 3.3.7 dat 'het bepalen van het beleid en de strategie van een vennootschap en de met haar verbonden onderneming in beginsel een aangelegenheid is van het bestuur' (tenzij dit 'bepalen van het beleid en de strategie' zo wordt uitgelegd en opgerekt dat het, als het 'meerdere', alles omvat wat onder het besturen valt, dus ook het 'mindere'). De verwijzing in r.o. 3.3.7 naar het ontbreken van een plicht van het bestuur de algemene vergadering 'daaromtrent te consulteren', maakt deze lacune niet anders, want is dan evenmin concludent (weer behoudens die tenzij).

Een andere vraag is wat met betrekking tot artikel 2:114a BW zou moeten gelden als er in de wet of de statuten wel een consultatieplicht staat die besluitvorming door de algemene vergadering vergt. M.i. kan dan, in het algemeen en kort gezegd, artikel 2:114a BW (1) wél worden ingezet als er een concreet bestuursvoornemen is waarop die plicht ziet, het bestuur aan die plicht geen opvolging geeft en het agenderingsverzoek ertoe strekt die plicht te effectueren, en (2) níet worden ingezet om de algemene vergadering eigener beweging, want bij gebreke aan zo'n concreet bestuursvoornemen, een besluit te kunnen laten nemen over het onderwerp waarop die plicht betrekking heeft. In het eerste geval is m.i. de algemene vergadering wel ter zake besluitbevoegd (de consultatieplicht is geactiveerd en daarop rust die bevoegdheid dan), in het tweede geval niet (de consultatieplicht is niet geactiveerd en kan niet worden gebruikt om via artikel 2:114a BW besluitvorming van de algemene vergadering te forceren). Dit antwoord lijkt mij (ook als zo'n consultatieplicht gericht zou zijn op bepaling van beleid en strategie) in de rede te liggen, wederom gelet op de wetsgeschiedenis van artikel 2:114a BW, maar staat even$\mathrm{min}$ in r.o. 3.3.7. ${ }^{35}$ Gaat het om een uit de wet of de statuten voortvloeiend goedkeuringsrecht van de algemene vergadering dan laat een vergelijkbare benadering zich voorstellen. ${ }^{36}$

34. Dit beslaat logischerwijs een breed palet aan specifieke beslissingen/handelingen, mede omvattend het al dan niet (1) aangaan of verbreken (op bepaalde condities) van een bepaald contract met een derde, (2) verrichten of opschorten (op bepaalde condities) van een bepaalde betaling aan een derde, of (3) aannemen of ontslaan (op bepaalde condities) van een bepaalde persoon als werknemer.

35. Staat er in de wet of de statuten niet zo'n consultatieplicht, dan kan niet via louter art. 2:114a BW alsnog een vorm van raadpleging van de algemene vergadering door het bestuur worden afgedwongen.

36. Zie A-G Timmerman in nr. 4.47 van zijn conclusie over de 'verschillende gradaties die de betrokkenheid van de aandeelhouders(vergadering) bij de vaststelling en uitvoering van beleid van het bestuur kan hebben', grofweg oplopend 'van slechts luisteren naar de opvattingen van aandeelhouders via het voeren van een dialoog naar een recht van consultatie en uiteindelijk goedkeuring van beslissingen van het bestuur'.
In lijn met het voorgaande ligt de gedachte dat de algemene vergadering een op grond van de wet of de statuten aan het bestuur toekomende bevoegdheid in beginsel niet eenvoudigweg naar zich toe kan trekken louter door middel van een daartoe strekkend besluit, bij gebreke aan de bevoegdheid ter zake.

\subsection{Wetsgeschiedenis en EU-recht}

Kortom, het ontkennende antwoord dat de Hoge Raad geeft op de centrale vraag van r.o. 3.3.5 snap ik, en vind ik als resultaat prima te verdedigen, ook in het licht van r.o. 3.3.8 met betrekking tot de Aandeelhoudersrichtlijn (die overwegingen overtuigen mij, ook in het licht van de conclusie van advocaatgeneraal Timmerman). ${ }^{37}$ Maar de onderliggende overwegingen wat betreft het Nederlandsrechtelijke kader (los van r.o. 3.3.8) hadden m.i. aan werfkracht en duidelijkheid gewonnen als juist ook de wetsgeschiedenis van artikel 2:114a BW daarbij was betrokken als basis naast de tekst en ratio van artikel 2:114a BW en niet alles was opgehangen aan r.o. 3.3.6 (waarover par. 5.8 hierna), maar r.o. 3.3.6 (toegesneden op het voorliggende geval) veeleer ter bevestiging en versterking had gediend van wat n.m.m. welbeschouwd - en anders dan de Hoge Raad kennelijk oordeelt - al in algemene zin volgt uit die wetsgeschiedenis, tekst en ratio met betrekking tot 'grenzen aan de in artikel 2:114a BW geregelde bevoegdheid van de daarin bedoelde aandeelhouders en certificaathouders'. Dat zou trouwens ook in lijn hebben gelegen met de opbouw van de conclusie van advocaat-generaal Timmerman.

Het voorgaande geldt m.i. temeer, omdat de bevindingen van de Hoge Raad in r.o. 3.3.8 over artikel 6 Aandeelhoudersrichtlijn goed aansluiten op die wetsgeschiedenis, waaruit al blijkt dat de Nederlandse wetgever ervan uitging met artikel 2:114a BW te hebben voldaan aan implementatie van die richtlijn. Of negeert de Hoge Raad die wetsgeschiedenis op het springende punt in r.o. 3.3.7, omdat het dan vooral gaat om schriftelijke uitlatingen van de minister van Justitie in een nota naar aanleiding van vragen van Kamerleden? ${ }^{38}$ Dat zou niet alleen selectief zijn, want in bijvoorbeeld het K./Le Roux-arrest ${ }^{39}$ over artikel 2:11 BW leunt de Hoge Raad wel en nadrukkelijk ook op zulke uitlatingen van de minister van Justitie (naast de tekst en ratio van art. 2:11 BW), maar ook gekunsteld, nu ook dergelijke uitlatingen deel uitmaken van de wetsgeschiedenis, en deze in dit geval bij herhaling zijn gedaan en aan duidelijkheid toch weinig te wensen overlaten.

Ik plaats nog twee observaties bij r.o. 3.3.4 jo. 3.3.8.

a. 'Acte clair'. De rechtsvergelijkende beschouwingen van advocaat-generaal Timmerman met betrekking tot de

37. A-G Timmerman in nrs. 4.94-4.137 van zijn conclusie. Zie eerder in vergelijkbare richting F.G.K. Overkleeft, Het agenderingsrecht voor aandeelhouders in beursvennootschappen: een aanzet tot (her)bezinning, Ondernemingsrecht 2009/167, waartegen o.a. J.H.M. Willems, Mogen aandeelhouders strategische onderwerpen agenderen?, Ondernemingsrecht 2017/116.

38. Zie ook Willems 2017, p. 656.

39. HR 17 februari 2017, NJ 2017/215 (K./Le Roux Fruit Exporters (Pty)), r.o. 3.4.2. 


\section{Maandblad}

Ondernemingsrecht

implementatie van de Aandeelhoudersrichtlijn in Duitsland, België, Frankrijk en het Verenigd Koninkrijk zullen de Hoge Raad een belangrijke steun in de rug hebben gegeven - anders dan Boskalis betoogde - geen prejudiciële vragen te stellen aan het Europese Hof van Justitie over de uitleg van artikel 6 Aandeelhoudersrichtlijn, maar het cassatieberoep meteen af te doen. ${ }^{40}$ Het lijkt erop, gelet ook op de bewoordingen van r.o. 3.3.8, dat hier volgens de Hoge Raad sprake is van een 'acte clair': de overtuiging van de nationale rechter dat de juiste toepassing van het EUrecht niet alleen voor hem maar ook voor de rechterlijke instanties van de andere lidstaten en voor het Europese Hof van Justitie zo evident is, dat redelijkerwijs geen twijfel kan bestaan omtrent de wijze waarop de gestelde vraag moet worden beantwoord.

b. Weigering 'slechts in uitzonderlijke gevallen'. De Hoge Raad houdt in r.o. 3.3.4, in lijn met de wetsgeschiedenis van artikel 2:114a BW, ${ }^{41}$ de mogelijkheid open van weigering van een agenderingsverzoek ex artikel 2:114a BW in het geval de aandeelhouder op zich wel het recht heeft ex artikel 2:114a BW zo'n verzoek te doen (met betrekking tot een bespreekpunt of een stempunt) en voldoet aan de specifieke eisen die artikel 2:114a lid $1 \mathrm{BW}$ stelt, maar dan 'slechts in uitzonderlijke gevallen' én met de aantekening dat een grondslag voor zo'n weigering gelegen kan zijn in artikel 2:8 lid $2 \mathrm{BW}$ of artikel 3:13 lid $1 \mathrm{BW} .{ }^{42}$ Dit laatste impliceert al een hoge drempel.

De Hoge Raad verwijst daarbij niet naar de Aandeelhoudersrichtlijn (alleen in r.o. 3.3.8, maar dat gaat niet over weigering) of anderszins naar EU-recht, maar dit is hier wel relevant; in ieder geval waar het - zoals in casu - gaat om een beurs-nv waarop artikel 2:114a BW toepassing vindt, maar denkelijk ook bij een niet-beursgenoteerde nv. ${ }^{43}$ Weliswaar bepaalt de Aandeelhoudersrichtlijn in $\mathrm{nr} .7$ van de considerans dat ' $[\mathrm{d}] \mathrm{e}$ aandeelhouders in beginsel de gelegenheid [moeten] krijgen om punten op de agenda van de algemene vergadering te plaatsen en ontwerpresoluties over agendapunten in te dienen' [cursivering BFA], wat subtiel de mogelijkheid van een uitzondering

40. Een ander voorbeeld van doorwrochte rechtsvergelijkende beschouwingen is de conclusie van A-G Timmerman voor HR 18 juli 2007, NJ 2007/434 (ABN Amro). Zie recent A-G Timmerman in nrs. 3.7, 3.12-3.13 van ECLI:NL:PHR:2018:578.

41. Zie daarover A-G Timmerman in nrs. 4.23-4.26 van zijn conclusie.

42. Ik begrijp dit laatste zo dat art. 2:8 lid 2 BW en art. 3:13 lid 1 BW nevengeschikt worden genoemd ('of). Ik neem aan dat de in art. 2:8 lid $1 \mathrm{BW}$ bedoelde gedragsnorm een rol kan spelen bij toepassing van art. 2:8 lid $2 \mathrm{BW}$ of art. 3:13 lid $1 \mathrm{BW}$ in een concreet geval.

43. Dat de Aandeelhoudersrichtlijn gericht is op 'de uitoefening van bepaalde rechten van aandeelhouders in beursgenoteerde vennootschappen' [cursivering BFA] laat onverlet dat de Nederlandse wetgever ervoor gekozen heeft art. 6 ervan te implementeren in art. 2:114a BW dat ook van toepassing is op de niet-beursgenoteerde nv. Ik acht het goed voorstelbaar dat dan gezegd kan en moet worden dat de Aandeelhoudersrichtlijn, in zoverre, vrijwillig ook is toegepast op zo'n niet-beursvennootschap. op de regel impliceert, ${ }^{44}$ tegelijkertijd volgt uit het EUrechtelijke doeltreffendheidsbeginsel dat de door de EUrechtsorde verleende rechten hun volle werking moeten hebben; daaraan wordt geen afbreuk gedaan door de toepassing van een nationaal voorschrift omtrent misbruik van recht, indien dat voorschrift zo wordt toegepast dat de doelstelling van de Europese regeling niet wordt doorkruist. $^{45}$

Daarbij verdient mede aandacht (1) dat het EU-recht een algemeen beginsel kent dat zich keert tegen 'misbruik van recht', ${ }^{46}$ (2) dat onzeker is of en in welke mate het EUrecht de beperkende werking van de redelijkheid en billijkheid als algemeen beginsel kent, ${ }^{47}$ en (3) dat niet uitgesloten wordt geacht dat de Nederlandse regels inzake de beperkende werking van de redelijkheid en billijkheid (zoals art. 2:8 lid $2 \mathrm{BW}$ ) in bepaalde gevallen een werking ten aanzien van EU-recht kunnen hebben die vergelijkbaar is met die van de nationale bepalingen inzake misbruik van recht (vgl. art. 3:13 BW), wat wil zeggen 'dat de toepassing geschiedt binnen het kader van de randvoorwaarden van gelijkwaardigheid en doeltreffendheid, waarbij het Unierecht buiten toepassing wordt gelaten in een bijzondere situatie waarvan niet kan worden gezegd dat daardoor afbreuk wordt gedaan aan zijn volle werking en uniforme toepassing. ${ }^{48}$

Afgaand op rechtspraak van het Europese Hof van Justitie en literatuur ter zake, worden dan door het EU-recht specifieke eisen gesteld aan toepassing van nationale bepalingen als artikel 2:8 lid $2 \mathrm{BW}$ of artikel 3:13 lid $1 \mathrm{BW}$ als grondslag voor een weigering in de zin van r.o. 3.3.4, wat weer drempelverhogend lijkt te werken voor het kunnen aannemen van 'uitzonderlijke gevallen' als bedoeld in r.o. 3.3.4. ${ }^{49}$

44. Art. 6 Aandeelhoudersrichtlijn bevat geen uitdrukkelijke weigeringsgrond. Zo staat daarin niet dat een aandeelhouder het agenderingsrecht slechts uitoefent nadat hij daaromtrent in overleg is getreden met het bestuur, bij gebreke waarvan het bestuur een agenderingsverzoek ex art. 2:114a BW mag weigeren, e.e.a. zoals bedoeld in best practice 4.1 .6 van de Nederlandse Corporate Governance Code.

45. Zie Asser/A.S. Hartkamp, Europees recht en Nederlands vermogensrecht (3-I), Deventer: Wolters Kluwer 2015, nr. 118.

46. Zie o.a. Asser/Hartkamp 2015, nr. 138.

47. Zie o.a. Asser/Hartkamp 2015, nr. 140.

48. Asser/Hartkamp2015, nr. 140.

49. Zie, naast noten 45-48 hiervoor, o.a. W. Snijders, Good faith as a Dutch and as a European concept, in: A.S. Hartkamp, C.H. Sieburgh, L.A.D. Keus, J.S. Kortmann \& M. Wissink (red.), The influence of EU law on national private law, Deventer: Kluwer 2014, p. 551: 'Those cases confirm in fact that the court is very reluctant in letting national norms like good faith or reasonableness and fairness interfere with the effect of European law. These norms may be applied by the national courts, but only as far as they can be said to coincide with a general principal of European law, leading to an identical result. Consequently the scope of this kind of national rules is in reality determined by the more restrictive general principles that are developed in European case law like abuse of right and fraud' en F.M. Peters \& F. Eikelboom, De strijd over het agenderingsrecht tussen Elliot en Akzo, WPNR 2017, p. 501. A.F.J.A. Leijten gaat hieraan kennelijk voorbij in nrs. 13 en 15 bij JOR 2018/142. 


\section{Maandblad}

Ondernemingsrecht

Ik verwijs hierna kortheidshalve naar de hoge drempel die geldt bij zo'n weigering, met inachtneming van het voorgaande.

\section{8 (Bepaling van) beleid en strategie}

Bij mijn aarzeling over de onderbouwing van r.o. 3.3.7 speelt ook dat de in r.o. 3.3.6 vervatte overwegingen over beleid- en strategiebepaling als bron hebben de ABN Amro-beschikking van de Ondernemingskamer, ${ }^{50}$ waarbij zij louter verwees naar 'het Nederlandse vennootschapsrecht en heersende opvattingen omtrent corporate governance' als basis daarvoor. Via de beschikkingen van de Hoge Raad inzake ABN Amro ${ }^{51}$ en $\mathrm{ASMI}^{52}$ is die brontekst ook, licht aangepast, in r.o. 3.3.6 terechtgekomen. ${ }^{53}$

Het door de Hoge Raad gesanctioneerde oordeel van de Ondernemingskamer is op geen enkel moment door de Hoge Raad zelf kenbaar onderbouwd ${ }^{54}$ (ook niet indirect, via een verwijzing naar de voorliggende conclusie van de advocaatgeneraal in de desbetreffende procedure, voor zover mogelijk), of zelfs maar gerelateerd aan de kernbepalingen over bevoegdheidsverdeling tussen het bestuur en de algemene vergadering van een vennootschap in Boek $2 \mathrm{BW}$, in het bijzonder artikel 2:129 BW en artikel 2:107 BW (waarop art. 2:114a BW naar de aard ook inwerkt, zoals r.o. 3.3.3 illustreert).

Natuurlijk, men kan met enige goede wil in die ABN Amrobeschikking (als herhaald in die ASMI-beschikking) lezen dat de Hoge Raad daarin een bepaalde uitleg geeft aan artikel 2:129 lid 1 BW (en art. 2:107 lid 1 BW), ${ }^{55}$ maar dit, laat staan

50. OK 3 mei 2007, ARO 2007/79 (ABN Amro), r.o. 3.17. Waarschijnlijk heeft de Ondernemingskamer daarbij (1) ook gekeken naar de destijds geldende Nederlandse Corporate Governance Code en (2) willen voortbouwen op OK 17 januari 2007, ARO 2007/21 (Stork), r.o. 3.14.

51. HR 18 juli 2007, NJ 2007/434 (ABN Amro), r.o. 4.3 ('De ondernemingskamer heeft in r.o. 3.17 terecht en in cassatie onbestreden vooropgesteld $\left.(. . .)^{\prime}\right)$.

52. HR 9 juli 2010, NJ 2010/544 (ASMI), r.o. 4.4 .1 (hier herhaalt de Hoge Raad zichzelf instemmend).

53. Men zou verder terug kunnen gaan naar met name HR 18 april 2003, NJ 2003/286 (RNA), r.o. 3.7 (waarin de Hoge Raad ook verwijst naar 'beleid', maar nog wat minder strak geformuleerd en gepolijst, getuige verwijzingen naar 'de continuiteit van (het beleid van) de vennootschap', 'het tot dan toe gevoerde beleid van de onderneming' en 'het beleid dat het bestuur (...) heeft gevoerd') en HR 21 februari 2003, NJ 2003/182 (HBG), r.o. 6.2 (waarin de Hoge Raad rept van 'het profiel van de gebruikelijke en normale ondernemingsactiviteiten van de vennootschap'). Overigens meandert de Hoge Raad in r.o. 3.3.6 van het onderhavige arrest wat: waar eerst wordt verwezen naar het beleid van het bestuur ('zijn beleid'), gaat het even verderop over 'het beleid en de strategie van de vennootschap'.

54. Los van de enkele koppeling die de Hoge Raad terloops aanbrengt in HR 9 juli 2010, NJ 2010/544 (ASMI), r.o. 4.4 .1 tussen het vennootschappelijk belang als normatief richtsnoer en het primaat met betrekking tot strategiebepaling via het woordje 'derhalve', welk verband door P. van Schilfgaarde in nr. 7 van zijn noot bij NJ 2010/544 ' [v] erwarrend en weinig logisch' wordt genoemd.

55. Zoals L. Timmerman, Verbindend vennootschapsrecht, variatie op een thema, in: B.F. Assink e.a. (red.), Verbindend recht (liber amicorum K.F. Haak), Deventer: Kluwer 2012, p. 519 doet, verwijzend naar 'een extensieve uitleg van art. 2: 129, lid 1 BW'. een motivering daarvoor, stáát nergens. En ja, het al in $1955^{56}$ door de Hoge Raad bevestigde beginsel dat een orgaan van de vennootschap de bij wet en statuten getrokken grenzen van zijn bevoegdheden niet mag overschrijden, is ook hier relevant, maar beantwoordt niet de vraag bij welk orgaan in beginsel het primaat met betrekking tot beleid- en strategiebepaling ligt, en waarom. ${ }^{57}$

Dat deze toch wat apodictische overwegingen desondanks zo'n eigen leven gaan leiden, en bijna als een bezweringsformule de kwestie van uitleg van bijvoorbeeld een wettelijke bepaling als artikel 2:114a BW gaan domineren, waarbij als het erop aankomt de totstandkoming van zo'n bepaling uit het oog wordt verloren en de betekenis van artikel 2:129 lid 1 BW en artikel 2:107 lid $1 \mathrm{BW}$ onbehandeld blijft, vind ik een minder gelukkige tendens, omdat de analyse dan al te losgezongen dreigt te raken van de juridische basis die in Boek 2 BW is vervat en - ook hier - in termen van werfkracht en duidelijkheid suboptimaal is.

Ten aanzien van die overwegingen in r.o. 3.3.6 over beleid- en strategiebepaling wijs ik nog op het volgende.

\section{a. Geschil}

Naarmate de open begrippen ('bepaling' van) 'beleid' en 'strategie' ruimer worden uitgelegd, valt, uitgaande van het in beginsel primaat van het bestuur ter zake, meer onder het bereik van de bevoegdheid van het bestuur (vgl. art. 2:129 lid 1 $\mathrm{BW}$ ) en minder onder het bereik van de bevoegdheden van de algemene vergadering (vgl. art. 2:107 lid $1 \mathrm{BW}$ ). Ook dit arrest neigt daarnaar, mede gelet op de laatste regel van r.o. 3.3.6, waaruit volgt dat voor zover bevoegdheden omtrent de inrichting van de (vennootschappelijke) organisatie toekomen aan het bestuur, de uitoefening daarvan 'samen[valt] met het bepalen van het beleid en de strategie van de vennootschap'. Dat deze begrippen van zichzelf weinig juridisch zijn, ${ }^{58}$ laat onverlet dat de inhoud - en dus de afbakening - ervan wel een centrale rol vervult bij die in beginsel bevoegdheidsverdeling

56. HR 21 januari 1955, NJ 1959/43 (Van Toorn/Schouten).

57. Hetzelfde geldt trouwens voor, wat A-G Timmerman in nr. 3.9 van ECLI:NL:PHR:2018:578 noemt, de 'rol van de rechter (...) in het Nederlandse systeem van vennootschapsrecht om bij de bevoegdheidsvraag na te gaan of de in wet en statuten vastgelegde bevoegdheidsverdeling is nageleefd'; de voorvraag betreft die verdeling zelf.

58. Al verwijst Boek $2 \mathrm{BW}$ er wel naar. Zie o.a. art. 2:141 lid $2 \mathrm{BW}$ over 'het strategisch beleid', art. 2:129 lid 4 BW over 'de algemene lijnen van het te voeren beleid' en art. 2:345 lid 1 BW over 'het beleid en de gang van zaken van een rechtspersoon'. Over die begrippen - en dan met name 'strategie' - wordt in de juridische literatuur ook wel geschreven (dikwijls onder verwijzing naar bedrijfseconomische literatuur), zie o.a. M. Holtzer, De invloed van werknemers op de strategie van de vennootschap (diss. Groningen), Deventer: Kluwer 2014, p. 21-51 (die erop wijst dat er geen overeenstemming bestaat over de invulling van 'begrippen als strategie en strategisch beleid') en L. Timmerman, De rol van vennootschappelijk belang en strategie bij het beschermen van beursvennootschappen, TvOB 2018, p. 15. Zie verder o.a. principe 1.1 van de Nederlandse Corporate Governance Code en de toelichting daarop, waaruit de Hoge Raad - de lijn volgend van HR 18 juli 2007, NJ 2007/434 (ABN Amro), r.o. 4.4 en HR 9 juli 2010, NJ 2010/544 (ASMI), r.o. 4.4.2.iii - inspiratie zou kunnen putten. 


\section{Maandblad}

Ondernemingsrecht

tussen het bestuur en de algemene vergadering, wat bij uitstek juridisch is. Dat de Hoge Raad hierin de praktijk veel richting geeft, kan m.i. niet worden gezegd.

Even los van de meer precieze juridische basis van de in r.o. 3.3.6 vervatte overwegingen over beleid- en strategiebepaling, en daargelaten dat voor een dergelijke in beginsel allocatie heus het nodige te zeggen valt, ${ }^{59}$ speelt de vraag hoe omgegaan moet worden met verschil van mening tussen deze organen, of tussen het bestuur en bepaalde aandeelhouders, omtrent het antwoord op de vraag of een bepaald onderwerp al dan niet onder (bepaling van) 'beleid en strategie' valt, en daarmee dus onder het in beginsel primaat van het bestuur ter zake. Dit raakt ook aan de vraag welke restbevoegdheden er onder artikel 2:107 lid $1 \mathrm{BW}$ overblijven voor de algemene vergadering. Het antwoord 'Geen' zou deze bepaling zinledig maken, wat niet voor de hand ligt. Het bepaalde in artikel 2:107 lid $1 \mathrm{BW}$ behoudt m.i. altijd wel een functie, maar het is, mede onder het gesternte van r.o. 3.3.6, nog niet zo heel eenvoudig voorbeelden te verzinnen - laat staan niet-buitenissige voorbeelden - van gevallen waarin deze bepaling toepassing kan vinden. ${ }^{60}$

Ik acht het voorstelbaar dat met betrekking tot een dergelijk verschil van mening de rechter kan worden aangezocht, wat dan wel ook ten minste enige nadere duiding van die begrippen vergt. De Hoge Raad laat zich daarover tot dusver dus niet echt uit, los van de laatste regel van r.o. 3.3.6, waarover ook sub c hierna. Gelet op het voorgaande kan het bestuur dan dus niet met een simpel machtswoord eenzijdig een einde aan die discussie maken en zo het onderwerp aan zich trekken. ${ }^{61} \mathrm{Bij}$ de beslechting van dat geschil kan - en zal - de rechter uiteraard wel acht slaan op de motivering door het bestuur waarom in zijn optiek een bepaald onderwerp onder (bepaling van) beleid en strategie valt, factoren als de uitgestippelde lijnen ter zake en de al verrichte uitvoering daarvan. Let wel, dit is een andere kwestie dan de vraag of een bepaald(e) beleid of strategie al dan niet wenselijk is. In het antwoord op die laatste vraag plegen rechters doorgaans niet, althans beperkt, te - willen - treden. We komen dan in de sfeer van wat de Hoge Raad

59. Zie o.a. B.F. Assink|W.J. Slagter, Compendium ondernemingsrecht, Deventer: Kluwer 2013, par. 51.1, p. 912-916. Zie voor een rechtsvergelijkende 'tour d' horizon' o.a. A-G Timmerman in nrs. 3.4.3-3.4.8 voor HR 9 juli 2010, NJ 2010/544 (ASMI).

60. Zie voor een voorbeeld A-G Timmerman in nr. 3.11 (slot) van ECLI:NL:PHR:2018:578.

61. Zie o.a. Willems 2017, p. 658: 'Wie maakt trouwens uit wat onder de strategie valt en valt iets onder strategie als het bestuur dat enigszins gemotiveerd uiteenzet?'

62. Zie o.a. HR 12 juli 2013, NJ 2013/461 (VEB/KLM), r.o. 3.4 .3 over de 'terughoudendheid' die de rechter past bij 'de beoordeling of een orgaan van een rechtspersoon bij het nemen van een besluit alle in aanmerking komende belangen naar redelijkheid en billijkheid heeft afgewogen en daarbij de nodige zorgvuldigheid in acht heeft genomen'. wel duidt als 'terughoudende' toetsing ${ }^{62}$ of 'marginale' toetsing. ${ }^{63}$

\section{b. Uitzondering}

In hoeverre kan een uitzondering worden gemaakt op de 'in beginsel' clausulering in r.o. 3.3.6? Dat bij dat bestuurlijk primaat een nuancering geldt in geval van een groepsmaatschappij (vgl. art. 2:24b BW) is goed voorstelbaar, omdat er dan vanuit de groepsleiding aandacht zal zijn voor (de bepaling van) het beleid en de strategie van de groep, waartoe die groepsmaatschappij ook behoort; het bestuur van die groepsmaatschappij moet daarmee dan rekening houden. Deze realiteit leidt echter niet zonder meer ertoe dat de algemene vergadering van die groepsmaatschappij 'dus' besluitbevoegd is ten aanzien van (de bepaling van) het beleid en de strategie van die vennootschap, wat zou doorwerken in artikel 2:114a BW. Dit laatste zal met name anders zijn als (1) de wet specifiek betrokkenheid van de algemene vergadering bij het beleid en/of de strategie mogelijk maakt (vgl. art. 2:107a BW), ${ }^{64}$ (2) de statuten dat doen (vgl. art. 2:129 lid 3-4 BW), of (3) het bestuur ter zake, bedoeld of onbedoeld, gerechtvaardigde verwachtingen heeft gewekt bij de aandeelhouders en artikel 2:8 BW ter zake doorwerkt (waardoor er in zoverre een wettelijke grondslag is). ${ }^{65}$ Het gaat dan niet zozeer om structurele betrokkenheid van de algemene vergadering via besluitvorming met betrekking tot (bepaling van) dat beleid en die strategie, als wel om situationele betrokkenheid.

Maar hoe zit het met de statutaire afwijkingsmogelijkheid waarvan artikel 2:129 lid $1 \mathrm{BW}$ rept, kan op grond daarvan bijvoorbeeld - ik beperk me daartoe maar even in deze bijdrage - de strategiebepaling integraal bij de algemene vergadering worden neergelegd? Dat is, bij mijn weten, nog geen door de Hoge Raad uitgemaakte zaak. Wordt onder 'strategie' verstaan zoiets als 'de visie en de keuzes (...) op hoofdlijnen (...) voor een langere periode' (die, overkoepelend, het uitgangspunt vormen voor de doelen en de deelbeslissingen op kortere ter-

63. Zie o.a. HR 18 mei 2018, RvdW 2018/623 (Holland Casino), r.o. 3.4.2 over 'marginale toetsing' in het kader van art. 26 lid 4 WOR, waarbij geldt dat (1) de ondernemer gehouden is om bij zijn besluitvormingsproces alle kenbare bij de onderneming betrokken gerechtvaardigde belangen te betrekken en (2) de Ondernemingskamer slechts nagaat of de ondernemer bij afweging van de betrokken belangen in redelijkheid tot zijn besluit heeft kunnen komen, waarbij zij aan de ondernemer beleidsvrijheid laat.

64. Boek 2 BW kent de nodige bepalingen die betrokkenheid van de algemene vergadering voorschrijven. Zie o.a. A.G.H. Klaassen, Bevoegdheden van de algemene vergadering van aandeelhouders (diss. Groningen), Deventer: Kluwer 2007.

65. A.F.J.A. Leijten rept in nr. 3 bij JOR 2018/142 van 'behoudens afwijkende wettelijke of statutaire regelingen (vandaar de steeds terugkerende frase 'in beginsel')'. Dit omvat m.i. ook art. 2:8 lid $1 \mathrm{BW}$, ook al is dit een generieke bepaling. Onder zo'n scenario zou kunnen vallen een geval als bedoeld door A.F.J.A. Leijten in nrs. 20-21 bij JOR 2018/142, waarin art. 2:8 lid $1 \mathrm{BW}$ dus dient als basis voor 'een recht voor aandeelhouders om een standpuntbepaling als stempunt te agenderen'. Zie ook noot 14 hiervoor. 


\section{Maandblad}

Ondernemingsrecht

mijn), ${ }^{66}$ en komt aan die afwijkingsmogelijkheid eigenstandige betekenis toe (los van art. 2:129 lid 3-4 BW), dan is het m.i. niet ondenkbaar, zeker niet in groepsverhoudingen althans besloten verhoudingen met een beperkt aantal aandeelhouders die voor de lange termijn en actief bij de vennootschap zijn betrokken (wat in casu niet speelde, maar in de praktijk veel voorkomt, zeker bij bv's maar ook bij nv's), dat de statuten de strategiebepaling primair toebedelen aan de algemene vergadering en in zoverre een beperking vormen als bedoeld in artikel 2:129 lid $1 \mathrm{BW} .{ }^{67}$ Het door de Hoge Raad in r.o. 3.3.6 gehanteerde beeld met betrekking tot de verdeling van bevoegdheden inzake (bepaling van) beleid en strategie van de vennootschap kantelt in zo'n scenario dan in zoverre.

Het bestuur wordt dan minder 'bedenker' van de strategie van de vennootschap en meer 'toepasser' daarvan door het bepalen en uitvoeren van daarop gericht beleid (ook op kortere termijn), ${ }^{68}$ maar wel met inachtneming van de gedragsnormen die volgen uit o.a. de Cancun-beschikking ${ }^{69}$ die de Hoge Raad ook noemt in r.o. 3.3.6 (dus met inbegrip van de eigen verantwoordelijkheid van het bestuur zich bij de vervulling van zijn taak te richten naar het belang van de vennootschap en de aan haar verbonden onderneming). ${ }^{70}$ In zoverre speelt dan logi-

66. Kamerstukken II $2008 / 09,32014$, 3, p. 11, waarin wordt uitgegaan van het bestuur als actor en als 'gangbare horizon voor strategische beslissingen in het bedrijfsleven' een periode van vijf tot tien jaar wordt genoemd. Principe 1.1 van de Nederlandse Corporate Governance Code gaat ervan uit dat het bestuur 'een visie op lange termijn waardecreatie van de vennootschap en de met haar verbonden onderneming' ontwikkelt en 'een daarbij passende strategie' formuleert, met de aantekening dat '[a]fhankelijk van de marktdynamiek' kortetermijnaanpassingen van de strategie nodig kunnen zijn. In de toelichting (p. 43) valt o.a. te lezen: 'Er zijn situaties denkbaar waarin de focus op de lange termijn niet langer aan de orde is voor een vennootschap, bijvoorbeeld in geval van faillissement of bij een overname, en het bestaansrecht van de vennootschap eindig is. De vennootschap leeft de Code dan na door uitleg te geven waarom lange termijn waardecreatie niet (langer) aan de orde is'

67. Andere voorbeelden zijn denkbaar, ook met open verhoudingen; ik noem een beursvennootschap met een controlerende aandeelhouder. Ik denk niet meteen aan een beursvennootschap met verspreide aandeelhouders die primair - op de korte termijn gerichte - beleggers zijn.

68. Zie ook o.a. HR 18 juli 2007, NJ 2007/434 (ABN Amro), r.o. 4.4 over 'de slagvaardigheid waarmee het bestuur moet kunnen handelen bij het bepalen en uitvoeren van de strategie van de aan de vennootschap verbonden onderneming', waaruit eveneens een onderscheid blijkt tussen 'bepalen' en 'uitvoeren'. In HR 18 juli 2007, NJ 2007/434 (ABN Amro), r.o. 4.3, HR 9 juli 2010, NJ 2010/544 (ASMI), r.o. 4.4.1 en r.o. 3.3.6-3.3.7 van het onderhavige arrest heeft de Hoge Raad het steeds over 'bepalen', niet (ook) over 'uitvoeren'. Die r.o. 3.3.6-3.3.7 laten wel open dat ook de 'bepaling' van 'beleid' (te onderscheiden van 'strategie') aan een ander orgaan dan het bestuur kan toevallen op grond van de wet of de statuten, wat tot op zekere hoogte kan raken aan de uitvoering van de strategie. Dit laat ik verder daar. Wel nog een vraag: zou bepaling van 'strategie en beleid' niet logischer zijn dan het omgekeerde?

69. HR 4 april 2014, NJ 2014/286 (Cancun), r.o. 4.2.1-4.3.

70. Wat A.F.J.A. Leijten in nr. 5 bij JOR 2018/142 leest in de verwijzing in r.o. 3.3.6 naar r.o. 4.3 van de Cancun-beschikking is denkbaar, maar het staat er niet; noch in r.o. 3.3.6, noch in r.o. 4.3 van de Cancun-beschikking. scherwijs niet de overweging uit de ASMI-beschikking ${ }^{71}$ dat het (in beginsel) aan het bestuur is, onder toezicht van de raad van commissarissen, te beoordelen of, en in hoeverre, het wenselijk is over de 'te volgen strategie' in overleg te treden met (externe) aandeelhouders. Dit laatste kan dan nog wel spelen bij het bepalen en uitvoeren van dat beleid (binnen de parameters van de door de algemene vergadering bepaalde strategie), waarover het bestuur dan in beginsel wel eigenstandig gaat.

Iets anders is dat bij de beraadslaging in en besluitvorming door de algemene vergadering over de strategie van de vennootschap n.m.m. ook de aandeelhouders zich dienen te richten naar het belang van de vennootschap en de aan haar verbonden onderneming (en de kenbare, gerechtvaardigde belangen van betrokkenen bij de vennootschap en de onderneming in aanmerking dienen te nemen), wat vergt dat losgekomen wordt van het beginsel dat het aandeelhouders vrijstaat om, binnen de grenzen van de in artikel 2:8 BW genoemde redelijkheid en billijkheid, hun 'eigen belangen te dienen'. ${ }^{72}$ Dit vertrekpunt is m.i. onvermijdelijk, nu de strategie van de vennootschap - evenals het beleid - onlosmakelijk verband houdt met het vennootschappelijk doel en haar belang dat, in de regel en vooral, bestaat in het bevorderen van het bestendig succes van de aan de vennootschap verbonden onderneming (waarbij ook belangen van andere betrokkenen bij de vennootschap en de onderneming een rol spelen). ${ }^{73}$ Dit vertrekpunt kan heel wel breder getrokken worden naar andere onderwerpen, dus ook waar het niet de strategie betreft, die onder de bevoegdheid van de algemene vergadering vallen. Ik kom daarop binnenkort elders terug.

Voor zover op grond van artikel 2:129 lid 1 BW volgens de statuten de strategiebepaling aan de algemene vergadering kan toekomen, en dat in een concreet geval ook gebeurt, werkt dit m.i. door in de toepassing van artikel 2:114a BW (niet alleen als bespreekpunt, maar ook als stempunt), omdat de algemene

71. HR 9 juli 2010, NJ 2010/544 (ASMI), r.o. 4.4.1. Ook in een ander perspectief komt dan te staan de in o.a. HR 9 juli 2010, NJ 2010/544 (ASMI), r.o. 4.5.3 bedoelde bevoegdheid van de algemene vergadering 'het bestuur en de $\mathrm{RvC}$ aan te spreken op het gevoerde beleid en de gevolgde strategie'; de nadruk ligt dan logischerwijs veeleer op het eerste. Timmerman (2012, p. 515) wijst erop, onder verwijzing naar HR 18 april 2003, NJ 2003/286 (RNA), r.o. 3.7, dat het bestuur 'een beschermingsmaatregel $[\mathrm{mag}]$ inzetten, als de continuïteit van het beleid van de vennootschap (m.i. in het bijzonder de uitgezette strategie) wordt bedreigd. Het bestuur mag dus in beginsel het eigen beleid beschermen' [zonder voetnoot in het origineel]. M.i. liggen de zaken niet per se anders als het primaat met betrekking tot de strategiebepaling bij de algemene vergadering ligt in plaats van bij het bestuur.

72. Aldus OK 12 oktober 2016, ARO 2016/140 (DeltaLloyd), r.o. 3.5, waarin de Ondernemingskamer dit als 'vanzelfsprekend' aanmerkt. Zie verder o.a. Kamerstukken II 2008/09, 31083, 29, p. 6: 'Zij [aandeelhouders, BFA] zijn, anders dan het bestuur en commissarissen, niet gebonden aan het brede richtsnoer van het belang van de vennootschap, maar mogen in beginsel hun eigen (rendements)belang nastreven. Wel dienen zij zich te houden aan de maatstaven van redelijkheid en billijkheid'.

73. HR 4 april 2014, NJ 2014/286 (Cancun), r.o. 4.2.1, waarover ook o.a. Assink 2017, p. 32-45, Timmerman 2012, p. 522-523 en Timmerman 2018, p. 15, die mede opmerkt: 'Tussen het vennootschappelijk belang en strategie bestaat verband' [zonder voetnoot in het origineel]. 


\section{Maandblad \\ Ondernemingsrecht}

vergadering dan in zoverre wel ook besluitbevoegd is. Kan een aandeelhouder artikel 2:114a BW dan inzetten om te bereiken dat ter algemene vergadering wordt gestemd over zo'n statutenwijziging? ${ }^{74}$ Dat lijkt mij zeker niet uitgesloten, gelet ook op artikel 2:121 BW.

\section{c. Inrichtingsurijheid}

Als gezegd besteedt de Hoge Raad in r.o. 3.3.6 aandacht aan het beginsel 'dat iedere vennootschap binnen de grenzen van de wet vrij is haar (vennootschappelijke) organisatie naar eigen inzicht in te richten', daarbij verwijzend naar de ASMIbeschikking. ${ }^{75}$ Deze passage volgt op de verwijzing naar de Cancun-beschikking $^{76}$ (de eigen verantwoordelijkheid van het bestuur zich te richten naar het belang van de vennootschap en de met haar verbonden onderneming) en de verduidelijking dat het vennootschappelijk belang 'de invoering, handhaving of beëindiging $[\mathrm{kan}]$ meebrengen van een bepaalde inrichting van de (vennootschappelijke) organisatie', wat hier kan worden bezien in het licht van de Antilliaanse beschermingsconstructie (die de Hoge Raad niet noemt, daarmee de overweging generiek houdend), ${ }^{77}$ welke constructie ruimer is dan louter de organisatie van Fugro als vennootschap.

Dit beginsel van inrichtingsvrijheid, dat m.i. ook toepassing vindt op bijvoorbeeld andere privaatrechtelijke rechtspersonen in Boek 2 BW, clausuleert de Hoge Raad door de strofe 'binnen de grenzen van de wet' [cursivering BFA]. Het is de vraag wat de Hoge Raad met dit gecursiveerde deel bedoelt. Ik zou dit ruimer willen verstaan dan alleen wetgeving in formele zin (wat weer ruimer is dan Boek $2 \mathrm{BW}$ ), nu bijvoorbeeld ook de statuten van de vennootschap hier een obstakel kunnen vormen waar de vennootschap niet zomaar omheen kan. Het lijkt mij zuiverder, hoewel iets minder precies, het beginsel van inrichtingsvrijheid - met inbegrip van de invoering, handhaving of beëindiging van een beschermingsconstructie - te plaatsen binnen de grenzen van het geldend recht, wat nog steeds de nadruk legt op de flexibiliteit van ons vennootschapsrecht die de Hoge Raad ook lijkt te willen uitlichten.

74. Een variant daarop is het introduceren in de statuten van een aanwijzingsbevoegdheid van de algemene vergadering in de zin van art. 2:129 lid $4 \mathrm{BW}$. Onder 'de algemene lijnen van het te voeren beleid op nader in de statuten aangegeven terreinen' kan mede de strategie worden verstaan. In deze variant kan de algemene vergadering sturing geven aan de strategiebepaling via zo'n aanwijzing aan het bestuur (wederom behoudens de eigen verantwoordelijkheid van het bestuur zich bij de vervulling van zijn taak te richten naar het belang van de vennootschap en de aan haar verbonden onderneming als bedoeld in r.o. 3.3.6, vgl. ook art. 2:239 lid $4 \mathrm{BW}$ ), wat moet worden onderscheiden van een scenario waarin de strategiebepaling op grond van de statuten primair bij de algemene vergadering zou liggen over de band van de in art. 2:129 lid $1 \mathrm{BW}$ bedoelde statutaire afwijkingsmogelijkheid. In die variant is art. 2:114a BW dus ook relevant.

75. HR 9 juli 2010, NJ 2010/544 (ASMI), r.o. 4.4.2.iv.

76. HR 4 april 2014, NJ 2014/286 (Cancun), r.o. 4.3, waarin de Hoge Raad dit afleidt uit r.o. 4.2.1-4.2.3 ('Uit hetgeen hiervoor in 4.2.1-4.2.3 is overwogen, volgt immers (...)').

77. In HR 9 juli 2010, NJ 2010/544 (ASMI) zag dit, gelet op o.a. r.o. 4.5.3, kennelijk mede op de benoeming van bepaalde personen tot adviseur van het bestuur en de raad van commissarissen, wat betrekking heeft op de organisatie van ASMI als vennootschap.
De laatste zin van r.o. 3.3.6 is een tikkeltje raadselachtig. Wil de Hoge Raad hiermee zeggen dat alleen voor zover bevoegdheden omtrent de - invoering, handhaving of beëindiging van een bepaalde - inrichting van de (vennootschappelij$\mathrm{ke}$ ) organisatie toekomen aan het bestuur, de uitoefening daarvan samenvalt met het bepalen van het beleid en de strategie van de vennootschap? ${ }^{78}$ Dit zou tot het ongerijmde resultaat leiden dat waar die bevoegdheid toekomt aan de algemene vergadering (zie hiervoor), de uitoefening daarvan niet samenvalt met het bepalen van het beleid en de strategie van de vennootschap. Het onderwerp zou dan van kleur verschieten al naar gelang die bevoegdheid toekomt aan het bestuur of de algemene vergadering. Ik zou de laatste zin van r.o. 3.3.6 maar zo willen verstaan dat voor zover een orgaan van de vennootschap die bevoegdheid toekomt, de uitoefening daarvan samenvalt met het bepalen van het beleid en de strategie van de vennootschap. Denkbaar is daarbij dat meer dan één orgaan ter zake een bevoegdheid toekomt, bijvoorbeeld in geval de algemene vergadering op grond van de wet of de statuten een goedkeuringsrecht heeft met betrekking tot een bestuursbesluit ter zake of anderszins betrokken moet worden in de besluitvorming, zoals bij statutenwijziging en/of aandelenuitgifte. Dat kan ook spelen bij een beschermingsconstructie.

\subsection{Consequentie}

De boodschap van het arrest, en met name r.o. 3.3.7, is klaarblijkelijk dat de Hoge Raad categorisch niet wil dat aandeelhouders langs de weg van via artikel 2:114a BW afgedwongen besluitvorming door de algemene vergadering aandeelhoudersopvattingen over beleid en strategie van de vennootschap (of anderszins) tot uitdrukking kunnen brengen binnen de vennootschap, als het desbetreffende onderwerp buiten de bevoegdheid van de algemene vergadering valt; dus ook niet als de stemming waarvan agendering wordt verzocht geen rechtsgevolg zou hebben en wordt betiteld als een informele stemming, een aanbeveling, een motie of een peiling. ${ }^{79} \mathrm{Zij}$ zullen

78. Het hof memoreert in r.o. 18 dat de door Boskalis voorgestane 'aanbeveling tot ontmanteling van de Antilliaanse Beschermingsconstructie' volgens Boskalis 'de governance van de onderneming betreft en niet de strategie in eigenlijke zin; markten, productie, contracten, business model'. Willems 2017, p. 658 acht het 'moeilijk vol te houden' dat het willen handhaven van een beschermingsconstructie, zoals hier, 'nu echt iets [is] van de strategie van de vennootschap': 'Dat is toch in wezen niet meer dan een institutionele regeling van vennootschappelijke verhoudingen'. De Hoge Raad plaatst in r.o. 3.3.6 de daar bedoelde inrichtingsvrijheid, waaronder hier ook het lot van de Antilliaanse beschermingsconstructie valt, dus in het kader van 'het beleid en de strategie van de vennootschap'. Zie ook A.F.J.A. Leijten in nrs. 4-5 bij JOR 2018/142, volgens wie "het handhaven van een beschermingsconstructie meer "beleid" [is] dan "strategie (in eigenlijke zin)"”.

79. Ook als de stemming geen rechtsgevolg heeft, is nog steeds sprake van een stempunt en niet van een bespreekpunt, zo redeneert de Hoge Raad klaarblijkelijk. Kennelijk anders R.G.J. Nowak in zijn noot bij JOR 2016/181. Het ligt, gelet op r.o. 3.3.7, m.i. in de rede dat ook als ter algemene vergadering (dus los van art. 2:114a BW) wordt verzocht om een informele stemming, het in stemming brengen van een aanbeveling of motie, dan wel een peiling, en het desbetreffende onderwerp niet onder de bevoegdheid van de algemene vergadering valt, de voorzitter het verzoek mag weigeren. Zie nader A-G Timmerman in nrs. 4.55-4.76 van zijn conclusie en A.F.J.A. Leijten in nrs. 16-17 bij JOR 2018/142. 


\section{Maandblad}

Ondernemingsrecht

zich, tenzij de vennootschap meewerkt aan het agenderen van een stempunt dat buiten de bevoegdheid van de algemene vergadering valt, en afgezien van het agenderen van bespreekpunten en/of stempunten die binnen de bevoegdheid van de algemene vergadering vallen, in beginsel moeten redden met (1) de aan iedere aandeelhouder toekomende bevoegdheid als bedoeld in artikel 2:117 lid $1 \mathrm{BW}$ de algemene vergadering bij te wonen, daarin het woord te voeren en het stemrecht uit te oefenen, en/of (2) artikel 2:107 lid $2 \mathrm{BW}$, althans het voorts aan iedere aandeelhouder toekomende recht ter algemene vergadering zelfstandig vragen te stellen die de vennootschap dient te beantwoorden, ongeacht of deze betrekking hebben op punten die op de agenda zijn vermeld. ${ }^{80}$

De Hoge Raad verstevigt daarmee, zeker gelet op de laatste zin van r.o. 3.3.7, het in beginsel bestaande bestuursprimaat ten aanzien van de bepaling van het beleid en de strategie van de vennootschap verder. Hij lijkt daarbij mede te redeneren vanuit het vennootschappelijk belang en de eigen bestuursverantwoordelijkheid ter zake, gelet ook op de verwijzing daarnaar in r.o. 3.3.6 en de eerste zin van r.o. 3.3.7 waarin r.o. 3.3.6 generiek wordt aangehaald, waarbij opmerking verdient dat die verwijzing opmerkelijk genoeg in r.o. 3.3.7 niet pregnant terugkomt: de nadruk ligt in r.o. 3.3.7 na de eerste zin op de eerste alinea van r.o. 3.3.6 (over beleid- en strategiebepaling), niet de tweede alinea (over die eigen bestuursverantwoordelijkheid). Een vraag die intussen wel gesteld kan worden, en die ook in het middel besloten lag, ${ }^{81}$ is in hoeverre dit een en ander - kort gezegd: wel bespreken, niet stemmen - strookt met de praktijk van andeelhoudersvergaderingen bij beursvennootschappen, en dan met name de relatief lage opkomst van aandeelhouders ter algemene vergadering (en het dikwijls al vooraf uitgebracht zijn van de stemmen door aandeelhouders ex art. 2:117b BW). Maar dat maakt voor de Hoge Raad, die hier streng is, dus geen verschil. ${ }^{82}$

Misschien, héél misschien, constateren we over een paar jaar wel dat hier, al met al, een vennootschapsrechtelijk tekort met betrekking tot aandeelhoudersbetrokkenheid is ontstaan,

80. Dit laatste benadrukt de Hoge Raad in HR 9 juli 2010, NJ 2010/544 (ASMI), r.o. 4.6, onder verwijzing naar de Aandeelhoudersrichtlijn, maar herhaalt hij niet in het onderhavige arrest. HR 9 juli 2010, NJ 2010/544 (ASMI), r.o. 4.6 bevat overigens ook een beperking: 'Daarbuiten hebben aandeelhouders geen recht op het verstrekken van door hen afzonderlijk verlangde informatie. Het recht op nadere inlichtingen is een recht van de AvA als orgaan van de vennootschap, verleend met het oog op vennootschappelijke rekening en verantwoording'

81. Zie het middel in nr. 2.3.ii, alsmede het hof in r.o. 3.18 (waarover ook de Hoge Raad in r.o. 3.2.2).

82. Gelet ook op hetgeen A-G Timmerman uiteenzet in nrs. 4.69-4.70 van zijn conclusie, valt die uitkomst m.i. wel te begrijpen. Zie verder A-G Timmerman in nr. 4.47 van zijn conclusie over 'de kern van de omgang tussen bestuur en aandeelhouders', te weten (1) het luisteren door het bestuur naar de opvattingen van aandeelhouders door uitoefening van hun recht om het woord te voeren op de aandeelhoudersvergadering en (2) het voeren van een continue en constructieve dialoog met aandeelhouders, waarbij (3) geldt dat informatie-uitwisseling een 'voorwaarde [is] voor het kunnen plaatsvinden van een gemotiveerde uitwisseling van gedachten, ofwel van een zinvolle discussie’. want inzichten daaromtrent kunnen wijzigen. Zo werd nog niet zo lang geleden de drempel van artikel 2:114a lid $1 \mathrm{BW}$ verhoogd van $1 \%$ naar $3 \%$, ingegeven door enkele gevallen waarin artikel 2:114a BW werd aangewend door activistische aandeelhouders. ${ }^{83}$ Hetgeen de Hoge Raad overweegt in r.o. 3.3.7 vormt in wezen een extra barrière voor de toepassing van artikel 2:114a BW gericht op besluitvorming door de algemene vergadering. ${ }^{84}$

\subsection{Ontslag}

Ik noemde in paragraaf 5.8 sub b hiervoor al even de afwijkmogelijkheid die artikel 2:129 lid 1 BW of artikel 2:129 lid 4 BW biedt voor statutair maatwerk op het terrein van beleid en strategie, waarmee het beperkende effect van het arrest op de toepassing van artikel 2:114a BW gedempt kan worden. Een ander mogelijk effect van het arrest kan zijn dat toepassing van artikel 2:114a BW om een ontslagbesluit te agenderen (de 'nucleaire optie') in de praktijk aan populariteit zal winnen, vanuit de gedachte dat de algemene vergadering daarover in beginsel wél gaat (gelet op art. 2:132 en 2:134 BW), een casus zoals die voorlag in het arrest dan dus niet speelt, en overigens de potentieel blokkerende werking van artikel 2:8 lid $2 \mathrm{BW}$ of artikel 3:13 lid $1 \mathrm{BW}$ ten aanzien van artikel 2:114a BW door de Hoge Raad in r.o. 3.3.4 wordt beperkt tot 'uitzonderlijke gevallen' waarvoor een hoge drempel geldt.

Hier komt een andere vraag op, namelijk in hoeverre de rechtspraak genoemd in r.o. 3.3.6 inwerkt op anwending in zo'n geval van artikel 2:114a BW door één of meer aandeelhouders (of certificaathouders) die de drempel van artikel 2:114a lid 1 BW halen en ook voldoen aan de overige specifieke eisen als daarin vermeld. ${ }^{85}$ De overwegingen van de Ondernemingskamer in de Akzo Nobel-beschikking ${ }^{86}$ zijn daarbij relevant, met name die in r.o. 3.28, maar helemaal traceerbaar is het voor mij niet wat zij daar doet, ook omdat zij uiteindelijk haar oordeel laat oplossen in het ontbreken van gegronde redenen als bedoeld in artikel 2:350 lid $1 \mathrm{BW}$ tegen de achtergrond van de omstandigheden van het geval. ${ }^{87}$ Hierover valt veel te zeggen.

83. Zie o.a. A-G Timmerman in nrs. 4.28-4.31 van zijn conclusie.

84. Welbeschouwd schuilt in de laatste twee zinnen van r.o. 3.3.4 ook een beperking, zij het ééntje met een hoog uitzonderingskarakter.

85. Ik ga dus uit van een bijeengeroepen algemene vergadering. De problematiek van art. 2:110-111 BW of aanwending van het enquêterecht (met name art. 2:349a BW) om via de Ondernemingskamer tot afgedwongen bijeenroeping te komen, laat ik rusten. Dit laatste speelde in o.a. Vzr. Rb. Amsterdam 10 augustus 2017, JOR 2017/260 (Elliott International/AkzoNobel), met een kritische noot van R.G.J. Nowak, respectievelijk OK 29 mei 2017, JOR 2017/261 (AkzoNobel) (in beide gevallen zonder succes voor de aandeelhouders die bijeenroeping wensten). Zie daarover o.a. Timmerman 2018, p. 14.

86. OK 29 mei 2017, JOR 2017/261 (AkzoNobel)

87. Timmerman 2018 , p. 16 schrijft dat z.i. 'de Ondernemingskamer het voorstel van een aantal aandeelhouders tot ontslag van de presidentcommissaris naar mijn mening op een wat hybride wijze bespreekt'. C.D.J. Bulten schrijft in nr. 13 van haar noot bij JOR 2017/261: 'De OK vindt dat Akzo het verzoek van Elliott kon opvatten als 'gericht op het verwerven van zeggenschap van de aandeelhouders over de opstelling van Akzo in reactie op de voorstellen van PPG' en daarmee over de strategie van Akzo. En die aandeelhouders hebben geen zeggenschap over de strategie'. 


\section{Maandblad \\ Ondernemingsrecht}

Met Vino Timmerman ${ }^{88}$ zou ik tot uitgangspunt willen nemen dat áls de algemene vergadering een bevoegdheid toekomt die aan het beleid en de strategie van de vennootschap raakt of kan raken, zoals het ontslag van een bestuurder, zij die bevoegdheid op zichzelf heeft, ook ingeval deze wordt ingezet 'als breekijzer' om het beleid en de strategie te wijzigen; dit laatste leidt niet automatisch tot activering van artikel 2:8 lid $2 \mathrm{BW}$ of artikel 3:13 lid $1 \mathrm{BW} .{ }^{89}$ Daarop wijst - naast eerdere rechtspraak van de Ondernemingskamer zelf ${ }^{90}$ - bijvoorbeeld ook die rechtspraak genoemd in r.o. 3.3.6, waaruit immers volgt dat de algemene vergadering haar opvattingen ter zake 'tot uitdrukking [kan] brengen door uitoefening van haar in de wet en de statuten toegekende rechten'. Dit werkt in zo'n geval logischerwijs door in artikel 2:114a BW, gelet op r.o. 3.3.7: zo'n ontslag van een functionaris is dan immers een aangelegenheid van de algemene vergadering, niet van het bestuur. $^{91}$

Iets anders is dat het bestuur, afgaande op r.o. 3.3.4, dan kan proberen een spaak in de wielen te steken door een agenderingsverzoek ex artikel 2:114a BW te weigeren over de band van artikel 2:8 lid $2 \mathrm{BW}$ of artikel 3:13 lid $1 \mathrm{BW}$, en de verzoekende aandeelhouder zo te dwingen de gang naar de rechter te maken, maar zo'n weigering zal, getuige r.o. 3.3.4, juridisch gezien alleen in 'uitzonderlijke gevallen' stand kunnen houden, waarvoor een hoge drempel geldt. Een mogelijk alternatief is het (onder protest) honoreren van dat verzoek door het bestuur gevolgd door een beroep van de vennootschap op de rechter, zoals de Ondernemingskamer (op de voet van art. 2:346 lid $1 \mathrm{BW}$ ), gericht op het via een voorziening doen blokkeren van beraadslaging en stemming over dat ontslag ter algemene vergadering. $\mathrm{Nu}$ het niet voor de hand ligt dat het bestuur die hoge drempel betrekkelijk eenvoudig kan omzeilen door, in plaats van het agenderingsverzoek ex artikel 2:114a BW te weigeren conform r.o. 3.3.4, dat verzoek te honoreren en vervolgens de rechter te adiëren om hetzelfde resultaat te bereiken, ligt het in de rede dat de rechter dan alleen kan komen tot een 'nood breekt wet'-voorziening die een vergelijkbaar effect sorteert als weigering van zo'n agenderingsverzoek indien daarmee ook recht wordt gedaan aan die hoge drempel. ${ }^{92}$ In beide scenario's zal m.i. het bestuur ten overstaan van de rechter niet achterover kunnen leunen, maar moeten laten

88. Timmerman 2018, p. 16

89. Kennelijk anders A.F.J.A. Leijten in nr. 15 bijJOR 2018/142.

90. Zie o.a. OK 12 januari 2010, ARO 2010/24 (AHAM), r.o. 3.2-3.7, mede bevattend de meer toegespitste overweging dat 'het bepalen van de koers van de vennootschap weliswaar aan het bestuur is, maar dat aan de (...) algemene vergadering van aandeelhouders de bevoegdheid toekomt om - indien die koers haar onwelgevallig is - bestuurders te ontslaan en andere bestuurders te benoemen, uiteraard zolang zij daarmee niet in strijd handelt met hetgeen de redelijkheid en billijkheid vordert'.

91. De uitoefening van deze ontslagbevoegdheid dient uiteraard wel te geschieden met inachtneming van in het bijzonder art. 2:8 lid 1 BW. Ik laat dat hier rusten. Zie o.a. Assink 2017, p. 44.

92. Dat de Ondernemingskamer op de voet van art. 2:349a BW onder omstandigheden kan afwijken van dwingend recht, zoals al is uitgemaakt, is daarbij een relevant gegeven. Zie o.a. HR 14 september 2007 , NJ 2007/611 (Versatel), r.o. 4.2 en HR 25 februari 2011, NJ 2011/335 (Inter Access Groep), r.o. 3.9. zien dat en waarom er sprake is van een grond tot weigering van het agenderingsverzoek, of een grond voor het treffen van een voorziening door de rechter, waarmee die hoge drempel gehaald kan worden. ${ }^{93}$

Een ander mogelijk alternatief is het inroepen door het bestuur van de responstijd als bedoeld in best practices 4.1.6-4.1.7 van de Nederlandse Corporate Governance Code. Deze regeling gaat ervan uit dat één of meer aandeelhouders het voornemen hebben de agendering te verzoeken van een onderwerp dat kan leiden tot wijziging van de strategie van de vennootschap, bijvoorbeeld door het ontslag van één of meer bestuurders of commissarissen, waarbij het bestuur in de gelegenheid wordt gesteld een redelijke termijn in te roepen om hierop te reageren. Dit laatste laat zich ook voorstellen als een aandeelhouder meteen een agenderingsverzoek ex artikel 2:114a BW doet, dus zonder eerst het voornemen daartoe kenbaar te maken. Komt het inroepen van de responstijd (tot ten hoogste 180 dagen) feitelijk neer op afstel in plaats van uitstel, omdat het agenderingsverzoek kenbaar is ingestoken op behandeling van het onderwerp juist in die specifieke algemene vergadering en niet een latere, dan is het m.i. geen gekke gedachte dat het inroepen van die responstijd op één lijn gesteld kan worden met een weigering in de zin van r.o. 3.3.4, zodat daarvoor dezelfde hoge drempel geldt. Gaat het, kort gezegd, om uitstel zonder afstel (met inachtneming van best practice 4.1.7), dan speelt welbeschouwd een iets ander scenario. Een probleem dat daarbij opkomt, is dat de responstijd slechts een 'best practice' is (waarvoor in de code de 'pas toe of leg uit'-eis geldt) die wettelijke grondslag ontbeert en dat artikel 2:114a BW niet voorziet in een (statutaire) afwijkingsmogelijkheid, maar wel imperatief is geformuleerd ('wordt opgenomen'); dit e.e.a. nog los van de vraag naar doorwerking van EU-recht via de Aandeelhoudersrichtlijn. Aldus bezien komt n.m.m. het bepaalde in artikel 2:8 lid $2 \mathrm{BW}$ of artikel 3:13 lid $1 \mathrm{BW}$ ook hier in beeld als de inroeping door het bestuur van de responstijd wordt betwist door de betrokken aandeelhouder, ${ }^{94}$ zelfs met inachtneming van EU-recht als de Aandeelhoudersrichtlijn ook hier doorwerkt, wat ik bepaald meer

93. De zaak zal in beginsel anders liggen als het bestuur niet weigert als hier bedoeld, maar vervolgens (preferente) aandelen worden uitgegeven aan een beschermingsstichting waardoor de stemverhoudingen in de algemene vergadering wijzigen. In dat geval kan de verzoekende aandeelhouder de gang naar de rechter maken, mogelijk de Ondernemingskamer, waarbij echter het toetsingskader veeleer gezocht moet worden in HR 18 april 2003, NJ 2003/286 (RNA), r.o. 3.7; dat is een andere discussie. Zie o.a. Assink | Slagter2013, par. 76.5, p. 1389-1398.

94. In OK 6 september 2013, JOR 2013/272 (Cryo-Save), r.o. 3.9 baseert de Ondernemingskamer de werking van de responstijd kennelijk op de redelijkheid en billijkheid ex art. 2:8 lid $1 \mathrm{BW}$. Mij gaat dat te ver, indachtig ook de kritiek daarop van M.W. Josephus Jitta in nrs. 4-6 van zijn noot bij JOR 2013/272 die m.i. hout snijdt. Kennelijk anders A.F.J.A. Leijten in nr. 13 bij JOR 2018/142. Een statutaire bepaling als bedoeld door Timmerman 2018, p. 16 (hij neemt aan dat het succesvol inroepen van de responstijd in ieder geval mogelijk is wanneer 'de aandeelhouders zelf in de statuten akkoord zijn gegaan met de responstijd') kan daarbij natuurlijk wel van belang zijn. Zie verder o.a. F.G.K. Overkleeft, De positie van aandeelhouders in beursvennootschappen (diss. Rotterdam), Deventer: Wolters Kluwer 2017, p. 414-417. 


\section{Maandblad}

Ondernemingsrecht

voor de hand vind liggen dan het omgekeerde. ${ }^{95}$ Ook hier dus weer een hoge drempel.

Terzijde: werkt de Aandeelhoudersrichtlijn hier inderdaad door, dan zal dit de Nederlandse wetgever m.i. voor een aanzienlijk probleem plaatsen bij het verschaffen van een wettelijke basis aan de responstijd ${ }^{96}$ en het koppelen daarvan (ook) aan artikel 2:114a BW, nu de Aandeelhoudersrichtlijn daarmee niet goed te rijmen valt.

\section{$5.11 \mathrm{BV}$}

Tot slot een dwarsverband met het bv-recht.

Het arrest heeft m.i., mede gelet op r.o. 3.3.3-3.3.7, ook betekenis voor artikel 2:224a BW (de bv-rechtelijke pendant van art. 2:114a BW) wat betreft de in r.o. 3.3.5 gestelde centrale vraag. In mijn woorden:

'Artikel 2:224a BW geeft de daarin bedoelde aandeelhouders (of certificaathouders) níet het recht de vennootschap te verplichten een onderwerp óók ter stemming op de agenda van de algemene vergadering te (doen) plaatsen, als de algemene vergadering niet de bevoegdheid toekomt een besluit over dat onderwerp te nemen (dit geldt ook als die stemming geen rechtsgevolg heeft en wordt betiteld als een informele stemming, een aanbeveling, een motie of een peiling). ${ }^{97}$

Voor de beurs-bv zal artikel 2:114a lid $1 \mathrm{BW}$ mogelijk rechtstreeks gaan gelden, althans uitgaande van het op 27 februari-27 maart 2018 in internetconsultatie gebrachte voorontwerp ter implementatie van Richtlijn 2017/828/EU betref-

95. Zie o.a. A-G Timmerman in nr. 4.104 van zijn conclusie, waarin hij erop wijst dat de Aandeelhoudersrichtlijn 'ziet op de uitoefening van de in de lidstaten bestaande aandeelhoudersrechten' en dat de doelstelling ervan is 'aandeelhouders van beursvennootschappen de mogelijkheid te bieden hun bestaande rechten overal in de EU effectief uit te oefenen' [tweede cursivering BFA]. Past daarbij dat de responstijd, gelet op het effect van inroeping ervan, buiten het bereik van de Aandeelhoudersrichtlijn valt? Ik vind dat moeilijk voorstelbaar.

96. Ik noem het kabinetsvoornemen een wettelijke bedenktijd van maximaal 250 dagen te introduceren, waarover o.a. Kamerstukken II $2016 / 17,29826,70$, waarin wordt onderkend dat dan 'rekening gehouden [dient] te worden met het EU-regelgevend kader, waaronder de Europese richtlijnen betreffende de uitoefening van rechten van aandeelhouders in beursgenoteerde ondernemingen (richtlijn 2007/26/ EG), betreffende het openbare overnamebod (richtlijn 2004/25/EG) en de herziene tweede vennoot-schapsrichtlijn (richtlijn 2012/30/EU)'. Voornoemd probleem onderkende het kabinet trouwens eerder in Kamerstukken II 2008/09, 31083, 29, p. 11-12.

97. Er zijn ook wel relevante verschillen tussen art. 2:114a BW en art. 2:224a BW. Zo kent art. 2:224a lid 1 BW een drempel van 1\% (niet 3\%) en de eigenstandige weigeringsgrond van het 'zwaarwichtig belang van de vennootschap' (strikt genomen te onderscheiden van art. 2:8 lid 2 BW en art. 3:13 lid 1 BW, al lijkt de overgang een vloeiende). En zo zijn de Aandeelhoudersrichtlijn (die de Nederlandse wetgever niet ook vrijwillig heeft willen implementeren in art. 2:224a BW) en de Nederlandse Corporate Governance Code niet geschreven voor niet-beursvennootschappen. fende de langetermijnbetrokkenheid van aandeelhouders. ${ }^{98}$ Daarin wordt - m.i. terecht - geconstateerd dat ook bv's met een beursnotering onder het toepassingsbereik van deze richtlijn vallen en bevat het voorgestelde artikel 2:187 BW daarom een schakelbepaling voor de beurs-bv van richtlijnbepalingen die in het nv-recht zijn of worden geïmplementeerd, inclusief artikel 2:114a lid $1 \mathrm{BW}$.

Wat betreft mijn flankerende opmerkingen over kwesties als beleid en strategie, vennootschappelijk belang, bestuursverantwoordelijkheid en inrichtingsvrijheid: de relevantie daarvan is n.m.m. naar de aard evenmin beperkt tot het nv-recht. ${ }^{99}$

\subsection{Een laatste kanttekening}

Dat bij het arrest m.i. kanttekeningen geplaatst kunnen worden, moge duidelijk zijn. Deze laten evenwel onverlet dat de Hoge Raad met dit arrest een belangwekkende uitspraak heeft gedaan die qua uitkomst goed verdedigbaar is en in het logische verlengde ligt van kernuitspraken als zijn RNA-, HBG-, ABN Amro-, ASMI- en Cancun-beschikkingen: ${ }^{100}$ stuk voor stuk bouwstenen voor een evenwichtige doorontwikkeling van ons vennootschapsrecht.
98. Zie www.internetconsultatie.nl/langetermijnbetrokkenheidaandeel houders.

99. Zie vanuit het perspectief van een familievennootschap in de vorm van een bv o.a. Assink 2017, p. 32-47. 